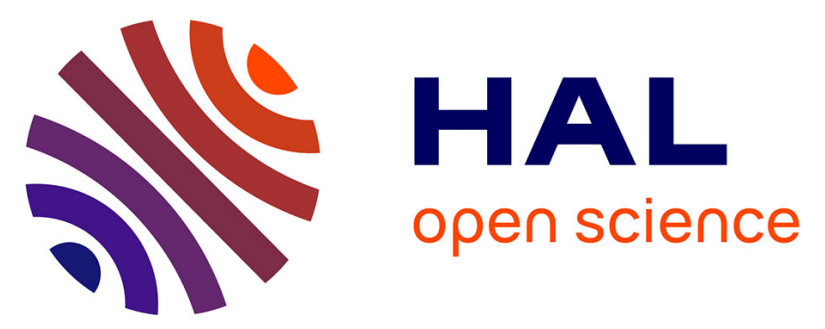

\title{
Behavioural responses of breeding arctic sandpipers to ground-surface temperature and primary productivity
}

Nicolas Meyer, Loïc Bollache, Matthias Galipaud, Jérôme Moreau, François-Xavier Dechaume-Moncharmont, Eve Afonso, Anders Angerbjörn, Joël Bêty, Glen Brown, Dorothée Ehrich, et al.

\section{To cite this version:}

Nicolas Meyer, Loïc Bollache, Matthias Galipaud, Jérôme Moreau, François-Xavier DechaumeMoncharmont, et al.. Behavioural responses of breeding arctic sandpipers to ground-surface temperature and primary productivity. Science of the Total Environment, 2021, 755 (2), pp.142485. 10.1016/j.scitotenv.2020.142485 . hal-02986001

\section{HAL Id: hal-02986001 https://hal.science/hal-02986001}

Submitted on 2 Mar 2021

HAL is a multi-disciplinary open access archive for the deposit and dissemination of scientific research documents, whether they are published or not. The documents may come from teaching and research institutions in France or abroad, or from public or private research centers.
L'archive ouverte pluridisciplinaire HAL, est destinée au dépôt et à la diffusion de documents scientifiques de niveau recherche, publiés ou non, émanant des établissements d'enseignement et de recherche français ou étrangers, des laboratoires publics ou privés.

\section{(c)(1)}

Distributed under a Creative Commons Attribution| 4.0 International License 


\title{
Behavioural responses of breeding arctic sandpipers to ground-surface temperature and primary productivity
}

\author{
Nicolas Meyer $^{\mathrm{a}, \mathrm{b}, *}$, Loïc Bollache ${ }^{\mathrm{a}, \mathrm{b}}$, Matthias Galipaud ${ }^{\mathrm{c}}$, Jérôme Moreau ${ }^{\mathrm{b}, \mathrm{d}}$, \\ François-Xavier Dechaume-Moncharmont ${ }^{\mathrm{e}}$, Eve Afonso ${ }^{\mathrm{a}}$, Anders Angerbjörn ${ }^{\mathrm{f}}$, Joël Bêty ${ }^{\mathrm{g}}$, Glen Brown ${ }^{\mathrm{v}}$, \\ Dorothée Ehrich $^{\mathrm{h}}$, Vladimir Gilg ${ }^{\mathrm{b}}$, Marie-Andrée Giroux ${ }^{\mathrm{i}}$, Jannik Hansen ${ }^{\mathrm{j}}$, Richard Lanctot ${ }^{\mathrm{k}}$, Johannes Lang ${ }^{\mathrm{b}, \mathrm{l}}$, \\ Christopher Latty ${ }^{w}$, Nicolas Lecomte ${ }^{\mathrm{m}}$, Laura McKinnon ${ }^{\mathrm{n}}$, Lisa Kennedy ${ }^{\mathrm{x}}$, Jeroen Reneerkens ${ }^{\mathrm{o}, \mathrm{p}}$, \\ Sarah Saalfeld ${ }^{\mathrm{k}}$, Brigitte Sabard ${ }^{\mathrm{b}}$, Niels M. Schmidt ${ }^{\mathrm{j}}$, Benoît Sittler ${ }^{\mathrm{b}, \mathrm{q}}$, Paul Smith ${ }^{\mathrm{r}}$, Aleksander Sokolov ${ }^{\mathrm{s}}$, \\ Vasiliy Sokolov $^{\mathrm{t}}$, Natalia Sokolova ${ }^{\mathrm{s}}$, Rob van Bemmelen ${ }^{\mathrm{u}}$, Øystein Varpe ${ }^{\mathrm{y}, \mathrm{z}, \mathrm{aa}}$, Olivier Gilg ${ }^{\mathrm{a}, \mathrm{b}}$ \\ a UMR 6249 Chrono-environnement, Université de Bourgogne Franche-Comté, 16 route de Gray, 25000 Besançon, France \\ ${ }^{\mathrm{b}}$ Groupe de Recherche en Ecologie Arctique, 16 rue de Vernot, 21440 Francheville, France \\ c Department of Evolutionary Biology and Environmental Studies, University of Zurich, Winterthurerstrasse 190, 8057 Zurich, Switzerland \\ ${ }^{\mathrm{d}}$ Université de Bourgogne Franche-Comté, Equipe Ecologie-Evolution, UMR 6282 Biogéosciences, 6 Bd Gabriel, 21000 Dijon, France \\ e Univ Lyon, Université Claude Bernard Lyon 1, CNRS, ENTPE, UMR 5023 LEHNA, F-69622 Villeurbanne, France \\ ${ }^{\mathrm{f}}$ Department of Zoology, Stockholm University, 10691 Stockholm, Sweden \\ g Département de Biologie, Chimie et Géographie and Centre d'Études Nordiques, Université du Québec à Rimouski, Rimouski, Québec, Canada \\ h Department of Arctic and Marine Biology, UiT - The Arctic University of Norway, 9037 Tromsø, Norway \\ ${ }^{\mathrm{i}}$ K.-C.-Irving Research Chair in Environmental Sciences and Sustainable Development, Département de Chimie et de Biochimie, Université de Moncton, Moncton, NB, Canada \\ ${ }^{j}$ Arctic Research Centre and Department of Bioscience, Aarhus University, 4000 Roskilde, Denmark \\ ${ }^{\mathrm{k}}$ Division of Migratory Bird Management, U.S. Fish and Wildlife Service, Anchorage, AK, USA \\ ${ }^{1}$ Working Group for Wildlife Research at the Clinic for Birds, Reptiles, Amphibians and Fish, Justus Liebig University Giessen, D-35392 Giessen, Germany \\ m Canada Research Chair in Polar and Boreal Ecology and Centre d'Études Nordiques, Université de Moncton, Moncton, NB, Canada \\ ${ }^{\mathrm{n}}$ Department of Multidisciplinary Studies, York University Glendon Campus, Toronto, ON, Canada \\ - Rudi Drent Chair in Global Flyway Ecology, Conservation Ecology Group, Groningen Institute for Evolutionary Life Sciences (GELIFES), University of Groningen, Groningen, the Netherlands \\ p Department of Coastal Systems, NIOZ Royal Netherlands Institute for Sea Research, Utrecht University, Texel, the Netherlands \\ q Chair for Nature Conservation and Landscape Ecology, University of Freiburg, Freiburg, Germany \\ ${ }^{\mathrm{r}}$ Environment and Climate Change Canada, Ottawa, ON, Canada \\ ${ }^{s}$ Arctic Research Station of Institute of Plant and Animal Ecology, Ural Branch, Russian Academy of Sciences, 629400, Zelenaya Gorka Str., 21 Labytnangi, Russia \\ ${ }^{\mathrm{t}}$ Institute of Plant and Animal Ecology of Ural Branch of Russian Academy of Sciences, Ekaterinburg, Russia \\ u Bureau Waardenburg, Culemborg, the Netherlands \\ ${ }^{v}$ Wildlife Research \&'Monitoring Section, Ontario Ministry of Natural Resources E Forestry, Peterborough, Ontario, Canada \\ ${ }^{\mathrm{w}}$ Arctic National Wildlife Refuge, U.S. Fish and Wildlife Service, Fairbanks, AK, USA \\ ${ }^{x}$ Trent University, 1600 West Bank Dr., Peterborough, ON, Canada \\ ${ }^{y}$ The University Centre in Svalbard, 9171 Longyearbyen, Norway \\ ${ }^{\mathrm{z}}$ Norwegian Institute for Nature Research, 5006 Bergen, Norway \\ aa Department of Biological Sciences, University of Bergen, 5020 Bergen, Norway
}

Most birds incubate their eggs, which requires time and energy at the expense of other activities. Birds generally have two incubation strategies: biparental where both mates cooperate in incubating eggs, and uniparental where a single parent incubates. In harsh and unpredictable environments, incubation is challenging due to high energetic demands and variable resource availability.

We studied the relationships between the incubation behaviour of sandpipers (genus Calidris) and two environ-mental variables: temperature and a proxy of primary productivity (i.e. NDVI). We investigated how these rela-tionships vary between incubation strategies and across species among strategies. We also studied how the relationship between current temperature and incubation behaviour varies with previous day's temperature. We monitored the incubation behaviour of nine sandpiper species using thermologgers at 15 arctic sites between 2016 and 2019. We also used thermologgers to record the ground surface temperature at conspecific $\mathrm{n}$ e $\mathrm{s} \mathrm{t} \mathrm{s}$ i t e s and extracted NDVI values from a remote sensing product.

We found no relationship between either environmental variables and biparental incubation behaviour. Con-versely, as ground-surface temperature increased, uniparental species decreased total duration of recesses (TDR) and mean duration of recesses (MDR), but increased number of recesses (NR). Moreover, small species showed stronger relationships with ground-surface temperature than large species. When all uniparental species were combined, an increase in NDVI was correlated with higher mean duration, total duration and number of re-cesses, but relationships varied widely across species. Finally, some uniparental species showed a lag effect with a higher nest attentiveness after a warm day while more recesses occurred after a cold day than was predicted based on current temperatures.

We demonstrate the complex interplay between shorebird incubation strategies, incubation behaviour, and en-vironmental conditions. Understanding how species respond to changes in their environment during incubation helps predict their future reproductive success.

\section{Introduction}

Most bird species maintain egg temperature through contact incubation to ensure embryo development (Deeming, 2002). Moreover, incubation also protects the eggs against environmental hazards (e.g. overheating or solar radiation; Brown and Downs, 2003) and predators (Weidinger, 2002). However, incubation is an energetically costly behaviour preventing adults from performing other activities, such as foraging (Yom-Tov and Hilborn, 1981). Because a parent's body condition can in turn influence both its ability to care (McNamara and Houston, 1996) and its probability of surviving until the next breeding event (Williams, 1966), the time devoted to incubation may have negative consequences for its fitness. To solve this trade-off, birds evolved a diversity of incubation strategies from biparental incubation where both mates cooperate to uniparental incubation, where only one adult incubates. Hence, the extent to which eggs are incubated depends on the incubation strategy but is also flexible and may vary with predation risk (Conway and Martin, 2000a; Fontaine and Martin, 2006; Ghalambor and Martin, 2002) and other environmental factors. Two main environmental factors known to partly explain the variability in incubation behaviour are temperature and food availability (Chalfoun and Martin, 2007; Conway and Martin, 2000b; Londono et al., 2008; Weathers and Sullivan, 1989). Sharing incubation duties may buffer the effect of such environmental factors on the pair's incubation behaviour but comes with coordination challenges (Bulla et al., 2016). By contrast, incubation behaviour of uniparental species may vary importantly with environmental conditions (e.g. Reneerkens et al., 2011; Tulp and Schekkerman, 2006).

In birds, the genus Calidris (Charadriiform, Scolopacids; henceforth referred to as "Calidris species") has been studied intensively as they show a diversity of breeding strategies (Pitelka et al., 1974; Reynolds and Székely, 1997; Székely and Reynolds, 1995). Male and female adults within pairs of Calidris species can either incubate nests cooperatively (henceforth referred to as "biparental species") or alone (henceforth referred to as "uniparental species"), and in a few species a mix of both strategies can be found within populations (see e.g. Bulla et al., 2017; Moreau et al., 2018; Reneerkens et al., 2011). Biparental incubation allows a quasi-continuous heat input into the eggs and gives both mates 
substantial time to forage (Bulla et al., 2014; Norton, 1972). Conversely, uniparental species have a constrained schedule as they must leave the nest unattended during foraging bouts (Tulp and Schekkerman, 2006). Moreover, uniparental species may incur higher incubation costs as some have been shown to maintain a higher incubation temperature, presumably to compensate for their decreased overall attentiveness (Reneerkens et al., 2011). However, nests of biparental species are also left unattended for short periods several times a day (e.g. during parental exchanges or when the attending adult is flushed from its nest). Such periods during which nests are left unattended are called incubation recesses (hereafter referred as "recesses"). Hence, both strategies may result in intermittent incubation with detectable recesses, but incubation patterns (e.g. number and duration of recesses) greatly vary between strategies (Meyer et al., 2020; Norton, 1972; Reneerkens et al., 2011; Smith et al., 2012b).

Many hypotheses have been formulated to describe the possible advantages that breeding in the Arctic might offer to birds (e.g., reduced parasite loads: Alerstam et al., 2003; Piersma, 1997; increased food availability during continuous daylight: Schekkerman et al., 2003; lower predation risk: Gilg and Yoccoz, 2010; McKinnon et al., 2010; but see Bulla et al., 2019). Yet, the harsh arctic weather can also negatively impact breeding activities (Martin and Wiebe, 2004; Mayfield, 1978; McKinnon et al., 2013; Meltofte et al., 2007; Reneerkens et al., 2016; Schmidt et al., 2019). For example, local conditions may have multiple and interacting negative effects on the adult and its clutch. In harsh conditions, breeding adults experience additional energetic costs to sustain their increasing metabolic rate (Piersma and Morrison, 1994; Tinbergen and Williams, 2002; Wiersma and Piersma, 1994), to keep their eggs warm during incubation bouts or to rewarm them after recesses (i.e. increased egg-cooling rate; Biebach, 1986; Conway and Martin, 2000b). Moreover, Calidris species cannot draw on substantial reserves, but instead rely on local resources, forcing them to feed regularly to sustain incubation and body maintenance (Drent and Daan, 1980; Klaassen, 2003; Klaassen et al., 2001; but see Morrison and Hobson, 2004). In addition, Calidris species feed on arthropods, the availability (i.e. abundance and activity) of which varies from day to day with local temperatures but also throughout the season and across years and sites according to e.g. the local climate, plant phenology or the timing of snowmelt (Bolduc et al., 2013; Hodkinson et al., 1996; Høye and Forchhammer, 2008; Kwon et al., 2019; Saalfeld et al., 2019).

To investigate the effect of local conditions on bird incubation behaviour, we needed proxies for thermal conditions as well as food availability. We used the temperature near the ground-surface as a proxy for the temperature experienced by incubating birds and their unattended eggs. We also used the ground-surface temperature to account for the day to day variability in arthropod availability. At a broader scale, arthropod's biomass and tundra vegetation are driven by the same environmental factors such as the local climate or the timing of snowmelt (Sweet et al., 2015). The NDVI (Normalized Difference Vegetation Index) is a widely used proxy for primary productivity and varies with such environmental variables (Jia et al., 2003; Raynolds et al., 2006; Reed et al., 1994). Hence, we used the NDVI as a proxy of secondary production (i.e. arthropods biomass) to account for the variability in arthropod availability throughout season and across years and sites (Sweet et al., 2015). We predicted that uniparental species would show stronger relationships between incubation behaviour and both environmental variables as compared to biparental species that experience lower individual energetic constraints (Bulla et al., 2015). We also predicted that, when foraging efficiency is reduced (low prey availability under low NDVI and/or low temperature) and/or the adult's energetic needs increase (low temperature), uniparental species would increase the time spent off the nest. This behaviour would likely enhance their own survival at the expense of their embryos. Finally, we predicted that uniparental species could use their modest body reserves during harsh weather episodes to sustain a higher attentiveness than expected under the current conditions. This increased parental effort (i.e. the relative amount of time and energy allocated to parental care) would partially buffer deleterious effects on the developing embryos but adults may experience an energetic deficit. Consequently, a lag effect may emerge since the energetic deficit of a harsher day ("historical factor" sensus Cartar and Montgomerie, 1987) must be "paid back" in the near future to avoid impairing the adult's survival or its ability to attend its nest (McNamara et al., 1994). Conversely, we predicted that biparental species would not show such a lag effect as they cooperate to cope with bad conditions and would always have enough time to forage during off-bouts. Studying such lag effects offers an interesting insight into adult management of energy constraints during incubation. Although we could have expected the incubation behaviour to be driven only by adult's needs for survival (e.g. decreased attentiveness when cold) or only by the needs of embryos (strong lag effect), we assumed that incubation behaviour varies in a complex way due to the trade-off between current and future reproduction that intensifies in poor conditions.

In this study, we monitored the incubation behaviour of nine Calidris species, with different incubation strategies, during four consecutive summer seasons at a circumpolar arctic scale (15 sites). First, we describe the variability in the relationship between ground-surface temperature and incubation behaviour across strategies and species. Second, we assess how incubation behaviour varies with NDVI. Third, we investigate the joint effects of NDVI and ground-surface temperature on species-specific incubation behaviour. Finally, we examine the lag effects of past temperatures (i.e. during previous $24 \mathrm{~h}$ ) on the behavioural responses of Calidris species to current ground-surface temperatures.

\section{Materials and methods}

\subsection{Study sites}

The study was conducted at 15 study sites across the Arctic during four consecutive summer seasons (2016-2019): Belyi Island (BELY; $\left.73.32^{\circ} \mathrm{N}, 70.09^{\circ} \mathrm{E}\right)$, Sabetta (SABE; $71.24^{\circ} \mathrm{N} 71.80^{\circ} \mathrm{E}$ ), Erkuta (ERKU; $\left.68.22^{\circ} \mathrm{N} 69.15^{\circ} \mathrm{E}\right)$, Hochstetter Forland $\left(\mathrm{HOCH} ; 75.15^{\circ} \mathrm{N} 19.70^{\circ} \mathrm{W}\right)$, Zackenberg (ZACK; $74.28^{\circ} \mathrm{N} 20.34^{\circ} \mathrm{W}$ ), Karupelv (KVPE; $72.50^{\circ} \mathrm{N}$ $24.00^{\circ} \mathrm{W}$ ), Bylot (BYLO; $\left.73.15^{\circ} \mathrm{N} 80.00^{\circ} \mathrm{W}\right)$, Igloolik (IGLO; $69.40^{\circ} \mathrm{N}$ $\left.81.60^{\circ} \mathrm{W}\right)$, East Bay (EABA; $\left.63.98^{\circ} \mathrm{N} 81.67^{\circ} \mathrm{W}\right)$, Churchill (CHUR; $58.70^{\circ} \mathrm{N} 94.08^{\circ} \mathrm{W}$ ), Utqiagivik (formerly Barrow; UTQI; $71.23^{\circ} \mathrm{N}$ $156.75^{\circ} \mathrm{W}$ ), Ammarnäs (AMMA; $65.96^{\circ} \mathrm{N} 16.29^{\circ} \mathrm{E}$ ), Burntpoint Creek (BURN; $55.14^{\circ} \mathrm{N} 84.20^{\circ} \mathrm{W}$ ), Canning River (CARI; $70.12^{\circ} \mathrm{N} 145.82^{\circ} \mathrm{W}$ ) and Longyearbyen (LONG; $78.19^{\circ} \mathrm{N} 15.83^{\circ} \mathrm{E}$ ). This circumpolar network of study sites (the "Interactions Working Group") offers a large diversity of productivity and temperature conditions within the Arctic biome (Fig. S1; Meyer et al., 2020).

\subsection{Study animals and nest detection}

We monitored the incubation behaviour of nine Calidris species (among the 18 known species in this genera; Del Hoyo et al., 1996) on 1090 nests distributed across the 15 study sites listed above (see Table S1). Four species showed a uniparental incubation strategy, including the little stint (Calidris minuta) and the Temminck's stint (Calidris temminckii) where either sex may incubate, as well as the pectoral sandpiper (Calidris melanotos) and the white-rumped sandpiper (Calidris fuscicollis) where only females incubate (Cramp and Simmons, 1983; Hildén, 1975; Parmelee et al., 1968; Pitelka et al., 1974). We also monitored four species with a biparental incubation strategy, including dunlin (Calidris alpina), Baird's sandpiper (Calidris bairdii), purple sandpiper (Calidris maritima) and semipalmated sandpiper (Calidris pusilla) (Ashkenazie and Safriel, 1979; Gill and Tomkovich, 2004; Holmes, 1966; Pierce, 1997). Finally, we monitored one species with a mixed strategy, the sanderling (Calidris alba), where some nests are incubated by one parent (male or female) and others are incubated by both (Moreau et al., 2018; Reneerkens et al., 
2014). Nests were found systematically by rope-dragging or opportunistically by walking through suitable breeding habitat, flushing incubating birds and/or following them visually as they walk back to their nest. Between one and three Calidris species were monitored at each site (Table S1; see distribution of species and location of study sites on figure 1 in Meyer et al., 2020).

\subsection{Incubation behaviour}

If nests were found during laying, we assumed that one egg was laid per day to infer the date of clutch initiation. For nests found during incubation, we floated at least two eggs per clutch to determine incubation stage (Hansen et al., 2011; Liebezeit et al., 2007; Mabee et al., 2006). A temperature probe (Flylead thermistor PB 5009 with $60 \mathrm{~cm}$ cable) coupled to a data logger (Tinytag Plus2 TGP-4020; Gemini Data Loggers Inc., West Sussex, U.K.) was placed in each nest. We attached probes to a vertical wooden or metal stick and placed the device at the centre of the clutch so that the surface of the probe was levelled with the top of the eggs. This ensures the probe made contact with the adult's brood patch during incubation. Flotation and device deployment took approximately 5 to $10 \mathrm{~min}$ and such automatized monitoring allowed us to limit nest visits and so disturbances (Hansen et al., 2011; Moreau et al., 2018). To reduce experimentally induced predation, all efforts were made to avoid leaving scent at the nest site (e.g. nothing laid on the ground except thermologgers) and data loggers and wires were buried or concealed using local vegetation and substrate. We used Tinytag Explorer 5.2 software (Gemini Data Loggers Inc., West Sussex, U.K.) to view and export tabular data.

Data loggers were capable of recording temperature information throughout the full incubation period, ca. three weeks in Calidris species (duration of storage capacity: 22.2 days; accuracy of measurement: $0.2{ }^{\circ} \mathrm{C}$; temperature range: -40 to $+125^{\circ} \mathrm{C}$ ). Data loggers continuously (every $1 \mathrm{~min}$ ) recorded the temperature inside the nest cup, which allowed us to infer when adults were incubating the clutch (see figure 1 in Moreau et al., 2018). Incubation behaviour was documented from the time the temperature probe was installed to the end of incubation (i.e., abandonment, hatching or predation), except for in a few cases when dataloggers were retrieved at the end of the field season and the nest was still active. As ambient temperatures in the Arctic are almost always lower than the incubation temperature (ca. $41^{\circ} \mathrm{C}$ ), changes in the temperature measurements allowed us to distinguish recesses (i.e. periods when the nest was left unattended) from incubation bouts. Starting and ending times of recesses were documented using a previously used temperature threshold value (i.e. the median incubation temperature calculated over $24 \mathrm{~h}$ periods minus $3{ }^{\circ} \mathrm{C}$; Bulla et al., 2014; Meyer et al., 2020; Moreau et al., 2018), with a recess beginning when the measured temperature dropped below the threshold temperature and ending when reaching it again (and figure 1 in Moreau et al., 2018; see also Tulp and Schekkerman, 2006).

This technique for measuring incubation behaviour requires at least $24 \mathrm{~h}$ of continuous monitoring. All shorter records were therefore removed from our analyses (166 nests; $15.2 \%$ ). In some cases, temperature probes sank into the soft substrate or were moved by adults, impairing our ability to record suitable temperatures. Consequently, monitoring records with all daily median temperatures below $36{ }^{\circ} \mathrm{C}$ were also removed from analyses ( 97 nests; $8.9 \%$ ) to prevent misinterpretations. This threshold value of $36{ }^{\circ} \mathrm{C}$ was chosen as it discriminates between good and bad records (Meyer et al., 2020). For the remaining 827 nests, we calculated three components of incubation behaviour for each day a nest was monitored: the total duration of recesses (TDR; directly related to attentiveness; Norton, 1972), the number of recesses (NR) and the mean duration of recesses (MDR; which is equal to TDR/NR). Note that these components describe the individual incubation behaviour of uniparental species only. For biparental species, they reflect the incubation behaviour of both parents during their respective incubation bouts, as we could not discern between adults.
Finally, as sanderling pairs may either display biparental or uniparental incubation behaviour, we split sanderling records into two subsets based on the measured total duration of recesses and number of recesses (after Moreau et al., 2018). When a lone parent incubates, the total duration of recesses and number of recesses are far higher than when both parents incubate and this allows us to discriminate between both strategies. Twenty nests (i.e., $17.4 \%$ of all sanderling nests) had days classified as biparental followed by days with uniparental incubation, probably due to the desertion of one adult. These nests were removed from the analyses (see Table S1 for more details on sample sizes).

\subsection{Ground-surface temperature}

In addition to monitoring nest temperature, one or several thermologgers were concomitantly recording the temperature in nearby conspecific nests that were no longer being incubated. These temperatures matched the thermal conditions within $2 \mathrm{~cm}$ from the surrounding ground-surface (henceforth-called "ground-surface temperature") at a nest location and during a given period (Fig. S2). As microclimates of nesting habitat differ across species (Fig. S3) but may be relatively consistent within species at each site, these records provide information about the specific microclimatic conditions prevailing in a given species' nesting habitat during a specified period of time. Such ground-surface temperatures may better reflect the thermal conditions birds must cope with during incubation, compared to traditional air temperature recordings measured at least one meter above the ground-surface (Steiger et al., 2013; Weathers and Sullivan, 1989).

To match temporally the incubation behaviour components (measured over 24-h periods in each nest) with ground-surface temperature measurements (recorded every minute in at least one empty conspecific nest), we first generated a mean ground-surface temperature per hour by averaging all measurements available for a given species in a given site. When no temperature data were available for a species in a site, this population was removed (e.g. the dunlin nest monitored at East Bay, see Table S1). We next calculated an overall mean temperature for each 24-h period by averaging hourly temperatures across all $24 \mathrm{~h}$. When temperatures were not available for all $24 \mathrm{~h}$ of a corresponding period of incubation monitoring, we did not provide that period with a mean temperature. As the ground temperature follows a strong daily pattern (Fig. S2 and S3; Steiger et al., 2013), this method ensured that every hour would have the same weight in the calculation of daily means (see Fig. S3).

At a few occasions, during the warmest hour of the day, groundsurface temperature was close to the threshold temperature used to detect recesses. Therefore, we removed all 24 -h periods when the groundsurface temperature exceeded $33^{\circ} \mathrm{C}$ at least once (1.6\% of all temperature recordings); this approach kept us from missing recesses due to such unusually high temperatures. Our final dataset contained 666 nests that had both behavioural and ground-surface temperature data.

\subsection{Primary productivity}

We used an indirect method to approximate the relative variation in resource availability to incubating adult shorebirds. Because arthropod abundance is driven by the same abiotic factors as primary productivity (e.g. local climate; Bolduc et al., 2013; Danks, 1999; Tulp and Schekkerman, 2008), we used the Normalized Difference Vegetation Index (NDVI), reflecting primary productivity, as a proxy to grasp the heterogeneity of resource abundance throughout the season and across years and sites.

The NDVI, the normalized difference between near infrared light and red light reflected from plants, has shown to be closely linked to primary productivity in the Arctic (Jia et al., 2003; Raynolds et al., 2006; Reed et al., 1994). This index varies from -1 to 1 (i.e., -1 for water, near 0 for bare ground and above 0 for vegetated areas; Neigh et al., 2008) 
and the value becomes more positive with increasing primary productivity (Kerr and Ostrovsky, 2003; Reed et al., 1994). This index is widely used in ecology to study trophic interactions (Pettorelli et al., 2005 and references therein) and has been shown to be positively related to arthropod abundance and biomass in arctic (Sweet et al., 2015) and other ecosystems (Lassau and Hochuli, 2008).

Here, we used NDVI measurements from satellite optical remote sensing. For each study site, the NDVI was extracted from composite images of the MOD13Q1-VI product provided by the Land Processes Distributed Active Archive Center (LP DAAC) using the "extract area

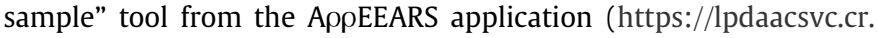
usgs.gov/appeears/). This product offers one NDVI measurement every 16 days with a $250 \mathrm{~m}$ spatial resolution. Each pixel is sensed several times during each 16-day period and a set of algorithms then selects the best measurement per pixel based on some quality indices (e.g. smallest view angle) and the NDVI value (i.e. a high NDVI is more trustworthy than a lower value). Resulting composite images were downloaded to cover the entire summer (from early June to late August) each year (2016-2019) and for each study site (i.e., 420 raster images used in total).

We limited the pixels used in our study in several ways to prevent biased estimates of NDVI. We used the summary quality index ("Pixel Reliability Index") and a detailed dataset ("VI Quality Assessment Science Data Sets") that described each pixel and the conditions during the NDVI measurement (Didan et al., 2015). First, we only used pixels where the Pixel Reliability Index equalled to "0","1" or "2" (i.e. "good data", "marginal data" and "snow/ice" respectively; Didan et al., 2015). Second, the "VI Quality Assessment Science Data Sets" was used to create a mask to isolate only useful pixels (e.g. qualified as "ocean coastlines and lake shorelines" and "Land [nothing else but land]"). Third, we set the NDVI values of pixels covered by snow to zero, as they influenced the calculation of the mean productivity at a site. Fourth, we controlled for the presence of shallow water caused by rapid snow melt to values of zero. The presence of shallow water and snow would result in artificially low negative NDVI scores and by changing their pixel values to zero we neutralized their effect on the NDVI score. Using this slightly modified NDVI database, we estimated the average NDVI over all filtered pixels at a given location for defined 16-day periods at each site (Fig. S1).

Since NDVI increases during the plant growing season and because algorithms select for the highest reliable NDVI measurement for every period, we assigned NDVI value to the last day of each 16-day period before estimating daily NDVI using linear interpolations. We used this index to characterize the overall productivity state of a study site (delimited in order to include all nests monitored in this study) at a given time, and not to characterize productivity at individual nest locations. This interpolated daily NDVI was significantly related to groundsurface temperature (Linear Model, linear coefficient $=5.10^{-3}, p$ value $<10^{-9}$ ), but daily temperatures only explained $1.30 \%$ of the NDVI variability.

\subsection{Data analysis}

Using the 666 nests that had ground-surface temperature data available (see Table S1), we first investigated how relationships between each incubation behaviour component (i.e. TDR, NR and MDR) and environmental conditions (i.e. temperature and NDVI) varied across incubation strategies. Incubation behaviour components were always used as response variables in separate mixed effect models with incubation strategy, ground-surface temperature and NDVI as fixed effects. Nest identity was used as a random effect to account for repeated measurements. From previous studies, we predicted non-linear relationships between incubation behaviour components and ground-surface temperature, with decreasing slopes (in absolute value) at higher temperatures (Conway and Martin, 2000b; Morton and Pereyra, 1985; White and Kinney, 1974). We therefore built a set of three candidate mixed effect models to account for such non-linear relationships: (1) a polynomial regression with a quadratic term for temperature, (2) a non-linear model based on the rectangular hyperbola equation provided by White and Kinney (1974) and (3) another non-linear model based on a Michalis-Menten saturation equation (i.e., predator's type II functional response). All models were built using the "nlme" package (Pinheiro et al., 2019) in the R software (version 3.6.2; R Core Team, 2019). We then retained the polynomial regression model for further analysis, as it fits the data the best based on its lower AIC value (Burnham and Anderson, 2004) for both the total duration of recesses and the number of recesses $(\triangle A I C>100$ between polynomial model and either Michaelis-Mentel or White-Kinney model for both incubation behaviour components) and was only slightly worse than the Michalis-Menten model for mean duration of recesses ( $\triangle$ AIC $=$ -13.0 between polynomial and Michaelis-Mentel models and $\triangle$ AIC $>100$ between polynomial and White-Kinney models). To examine how the relationships between each incubation behaviour component and environmental variables varied between strategies, we used Likelihood Ratio Tests to compare nested models with or without the interaction of interest. Moreover, we specified a first order autocorrelation structure using the corAR1 argument (Pinheiro et al., 2019) and day as the time unit to account for a higher similarity between closer days.

We then tested if the relationships between incubation behaviour components and environmental conditions varied across species that shared the same incubation strategy. Hence, for each strategy, we tested interaction effects between ground-surface temperature or NDVI and species on the response variables, using Likelihood Ratio Tests. We then built a new set of species-specific mixed effect models with incubation behaviour components as the response variable in separate models and both NDVI and ground-surface temperature as predictors to obtain comparable effect sizes for each species. We tested the significance of the quadratic term for temperature for each incubation component in each species, comparing models with Likelihood Ratio Tests. When the quadratic term for temperature significantly improved the model, we calculated the vertex corresponding to the abscissa of the local extrema of the equation provided by the model. In comparing vertex values across species, we were able to compare the temperature above which species no longer showed a relationship with the incubation behaviour. Using the same model structure as previously, we then tested the interaction effect of NDVI and ground-surface temperature for species that showed relationships between incubation behaviour and ground-surface temperature, comparing nested models with Likelihood Ratio Tests.

Finally, for each species where incubation behaviour significantly varied with ground-surface temperature, we ran another set of models to test the interaction effect between the current temperature and the temperature of the previous day on each incubation behaviour component. This allowed us to identify whether there were any lag effects from previous conditions and decisions on the relationship between current ground-surface temperature and each incubation behaviour component. The relationship between current temperature and incubation behaviour components was modelled with a second order polynomial when significant, and the interaction effect with past thermal condition was tested with Likelihood Ratio Tests.

\section{Results}

The relationships between incubation behaviour components and ground-surface temperature significantly differed between strategies, with only uniparental species responding to ground-surface temperature variations (Likelihood Ratio Tests, TDR: $\chi_{\mathrm{ddl}=2}^{2}=83.3, p<0.001$; NR: $\chi_{2}^{2}=208.0, p<0.001$; MDR: $\chi_{2}^{2}=145.0, p<0.001$; Fig. 1A-F). Uniparental species made significantly fewer (i.e. lower NR), but longer recesses (i.e. higher MDR) during days with colder ground-surface temperatures, overall spending more time off the nest (i.e. higher TDR) during these days (Figs. 1B, D, F and 2A). Similarly, the 

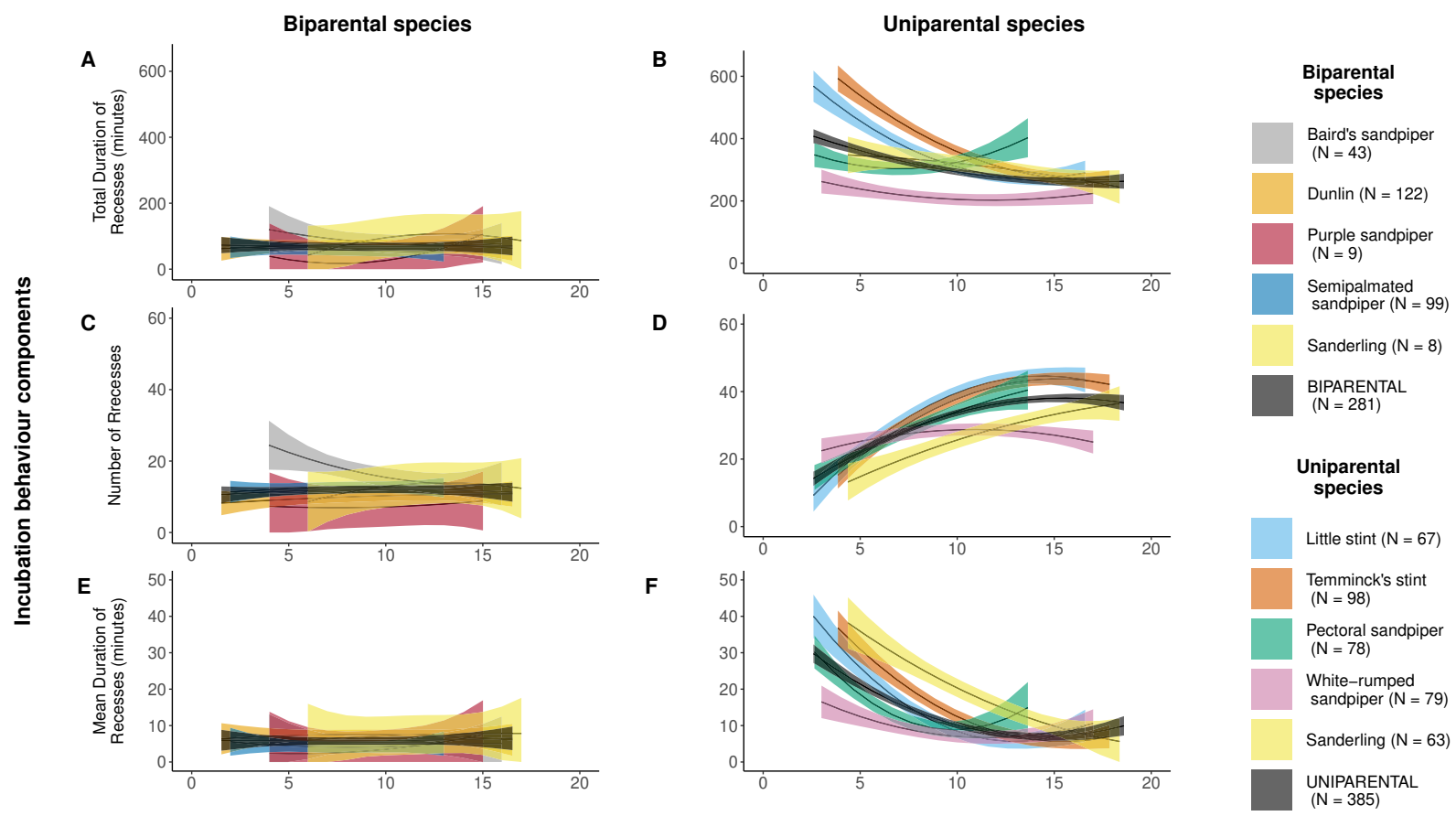

Daily average ground-surface temperature $\left({ }^{\circ} \mathrm{C}\right)$

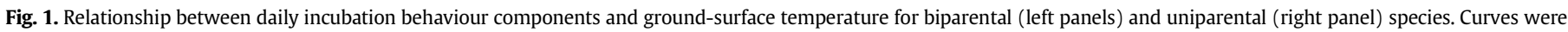

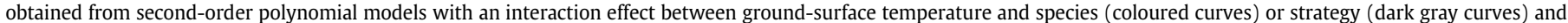

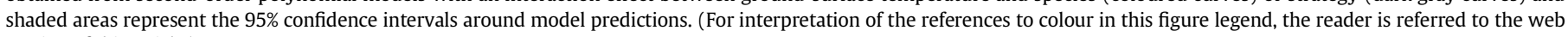
version of this article.)

relationships between total duration of recesses and NDVI, and between number of recesses and NDVI, differed between strategies (Likelihood Ratio Tests, TDR: $\chi_{1}^{2}=37.5, \mathrm{p}<0.001$; NR: $\chi_{1}^{2}=60.2, \mathrm{p}<0.001$; Fig. 2B), whereas the relationship between mean duration of recesses and NDVI was not significant (Likelihood Ratio Test; $\chi_{1}^{2}=3.12, p=$ 0.077 ). Uniparental species made significantly fewer and shorter recesses under low NDVI conditions, spending less time off the nest than when environments were more productive (but see the variability across uniparental species; Fig. 2B). Biparental species, on the other hand, made slightly more recesses at low NDVI, but the mean duration of recesses and total time spent off the nest did not vary with NDVI (Fig. 2B).

All uniparental species showed significant relationships between their incubation behaviour and ground-surface temperature. However, we found a high interspecific variability, as indicated by the significant interaction effect of temperature and species on incubation behaviour components (Likelihood Ratio Test, TDR: $\chi_{8}^{2}=137.9, \mathrm{p}<0.001$; NR: $\chi_{8}^{2}=106.0, \mathrm{p}<0.001$; MDR: $\left.\chi_{8}^{2}=70.3, \mathrm{p}<0.001\right)$. Little and Temminck's stints showed the strongest relationships, making about seven times more recesses, each 8 min shorter on average, for every one-degree temperature increase (Fig. 2A). In comparison, the relationships found for uniparental sanderlings and white-rumped sandpipers were markedly weaker with only two additional recesses, each approximately 3 min shorter, for every one-degree temperature increase (Fig. 2A). For the pectoral sandpiper, the relationship between the TDR and ground-surface temperature did not differ from most other uniparental species whereas they showed a similar effect size as little and Temminck's stints for the mean duration of recesses and as whiterumped sandpipers and uniparental sanderlings for the number of recesses (Fig. 2A). In contrast to uniparental species, biparental species showed a high interspecific consistency with mostly non-significant relationships between incubation behaviour components and groundsurface temperature (Fig. 1A, C, E, and Fig. 2A). Only Baird's sandpipers showed a significant negative relationship between the number of recesses and ground-surface temperature with 1.04 fewer recesses for every one-degree temperature increase (Likelihood Ratio Test, TDR: $\left.\chi_{1}^{2}=13.6, \mathrm{p}<0.001\right)$.

All incubation behaviour components of uniparental species, except for the number of recesses of pectoral sandpipers $\left(\chi_{1}^{2}=2.4, p=0.119\right)$ and the incubation behaviour components of uniparental sanderlings (TDR: $\chi_{1}^{2}<0.1, p=0.820$; NR: $\chi_{1}^{2}=0.2, p=0.641$; and MDR: $\chi_{1}^{2}=$ $0.4, p=0.545)$, showed a significant quadratic relationship with ground-surface temperature (Fig. 3). Pectoral sandpipers also showed a significantly lower vertex for total and mean duration of recesses overall $\left(6.8{ }^{\circ} \mathrm{C} ; \mathrm{Cl}_{95 \%}=\left[5.3^{\circ} \mathrm{C} ; 8.2{ }^{\circ} \mathrm{C}\right]\right.$ and $9.9{ }^{\circ} \mathrm{C} ; \mathrm{Cl}_{95 \%}=\left[8.5^{\circ} \mathrm{C} ; 11.2{ }^{\circ} \mathrm{C}\right]$, respectively; Fig. 3) relative to Temminck's $\left(16.7^{\circ} \mathrm{C} ; \mathrm{Cl}_{95 \%}=\left[14.9^{\circ} \mathrm{C}\right.\right.$, $\left.18.5^{\circ} \mathrm{C}\right]$ and $15.4 ; \mathrm{Cl}_{95 \%}=[14.2 ; 16.6]$; Fig. 3$)$ and little stints $\left(14.3^{\circ} \mathrm{C}\right.$; $\mathrm{Cl}_{95 \%}=\left[12.1{ }^{\circ} \mathrm{C}, 16.5{ }^{\circ} \mathrm{C}\right]$ and $13.0{ }^{\circ} \mathrm{C} ; \mathrm{Cl}_{95 \%}=\left[12.0{ }^{\circ} \mathrm{C} ; 14.0{ }^{\circ} \mathrm{C}\right]$; Fig. 3 ). In addition, we found that white-rumped sandpipers had a lower vertex than Temminck's and little stints for number of recesses and mean duration of recesses (respectively $10.6{ }^{\circ} \mathrm{C} ; \mathrm{Cl}_{95 \%}=\left[9.3^{\circ} \mathrm{C}\right.$, $\left.12.0{ }^{\circ} \mathrm{C}\right]$ and $11.7{ }^{\circ} \mathrm{C} ; \mathrm{Cl}_{95 \%}=\left[11.0{ }^{\circ} \mathrm{C} ; 12.3^{\circ} \mathrm{C}\right]$; Fig. 3). Using these species-specific vertices, we could delineate a temperature that separated a cold day (a slight change below this value was related to incubation behaviour variations) and a warm day (a slight change above this value was not related to incubation behaviour variations). When no vertex could be calculated (i.e. sanderlings), we consider a cold day to be under $12{ }^{\circ} \mathrm{C}$ (i.e., approximately the median vertex value) and a warm day to be above.

Relationships found between incubation behaviour components and NDVI differed between strategies. However, these relationships also varied markedly across species that shared the same strategy, in such a way that it prevented us from identifying strategy-specific patterns (Fig. 2B). Moreover, we found significant interaction effects between NDVI and ground-surface temperature as they relate to incubation behavioural components for some species (Fig. 4). Temminck's and little stints showed similar trends with stronger relationships between incubation behaviour and ground-surface temperature under productive 

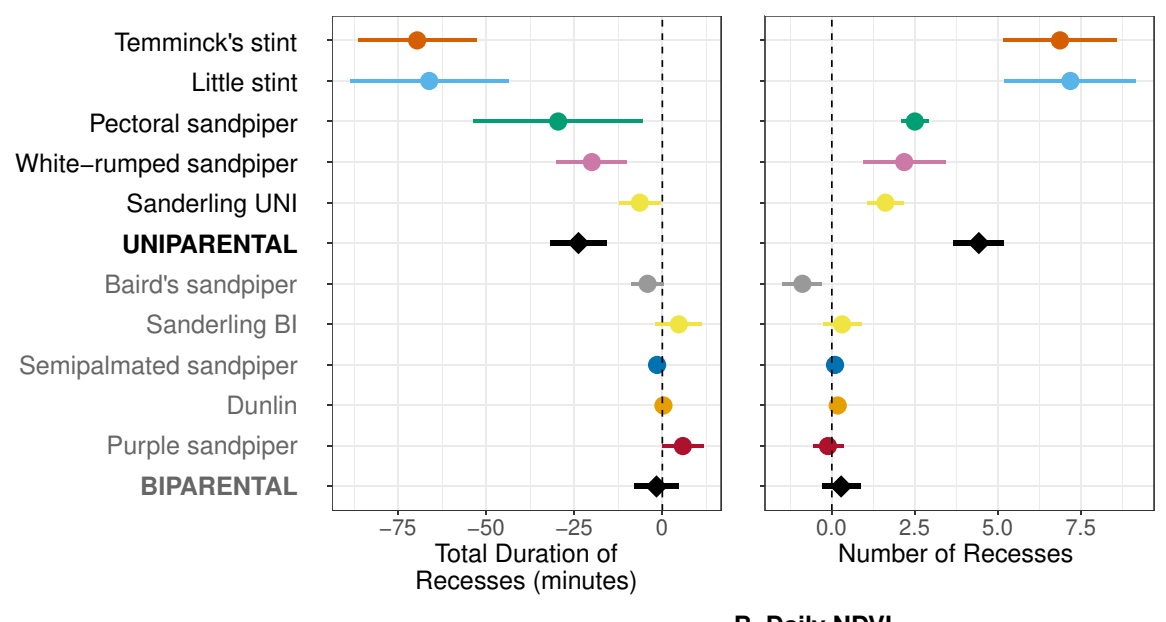

B. Daily NDVI

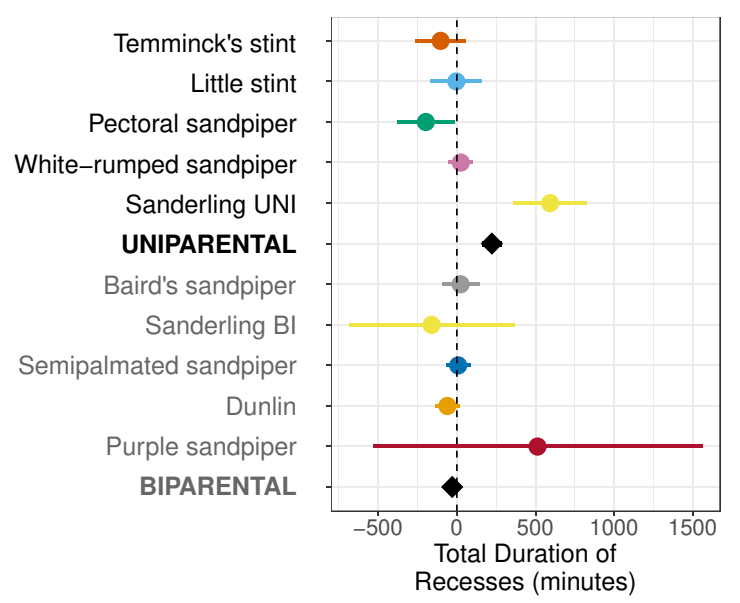

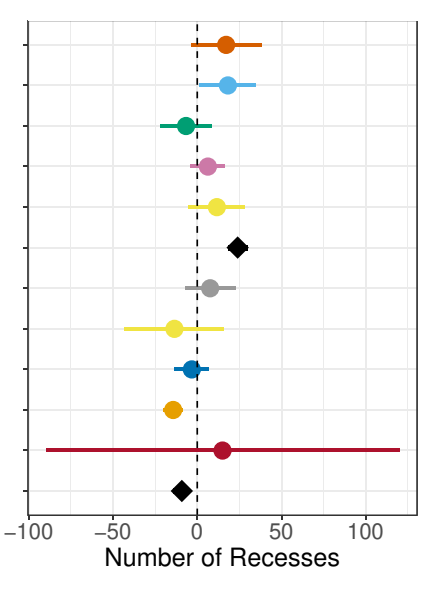

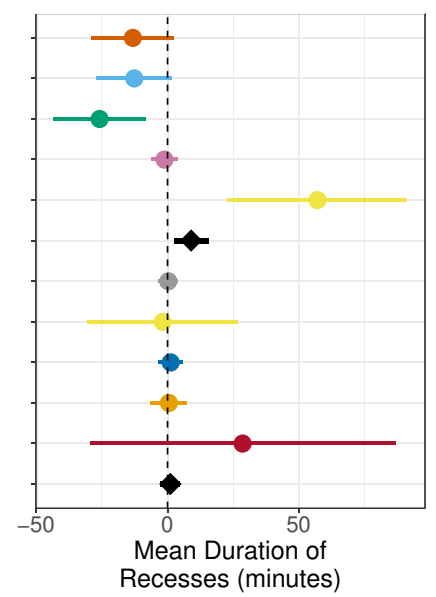

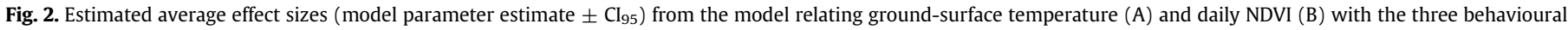

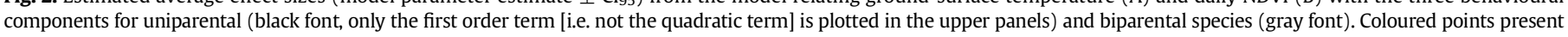

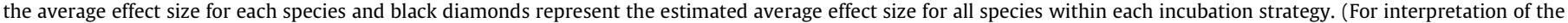
references to colour in this figure legend, the reader is referred to the web version of this article.)

conditions (only significant for NR in little stint: $\chi_{2}^{2}=8.3, p=0.016$; Fig. 4). On the other hand, in productive conditions, pectoral sandpipers maintained a higher attentiveness (i.e. a lower total duration of recesses) with shorter recesses in cold compared to warmer conditions, whereas the reverse was true under low productivity conditions (TDR: $\chi_{2}^{2}=17.6, p<0.001$; MDR: $\chi_{2}^{2}=34.4, p<0.001 ;$ Fig. 4). Finally,
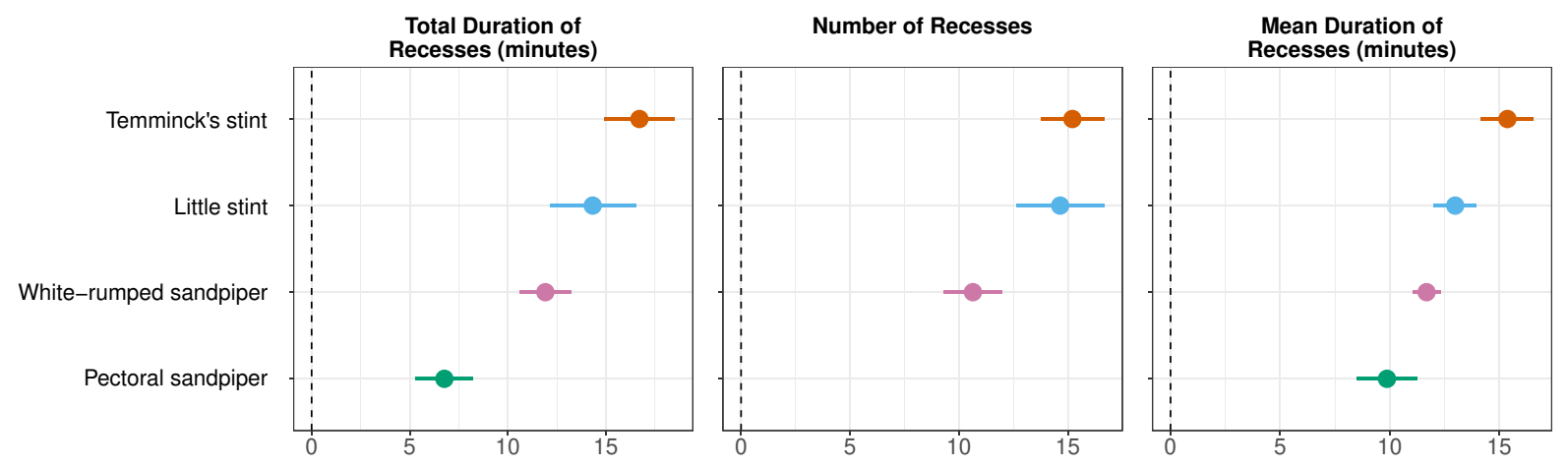

Daily average ground-surface temperature $\left({ }^{\circ} \mathrm{C}\right)$

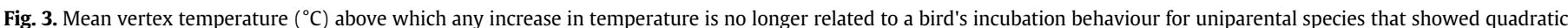

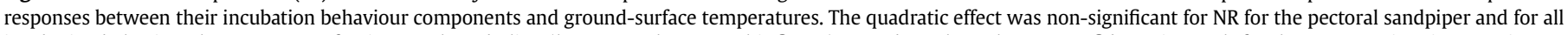

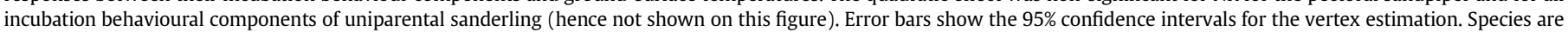
listed from top to bottom according to their mean body weights (smallest to largest). 

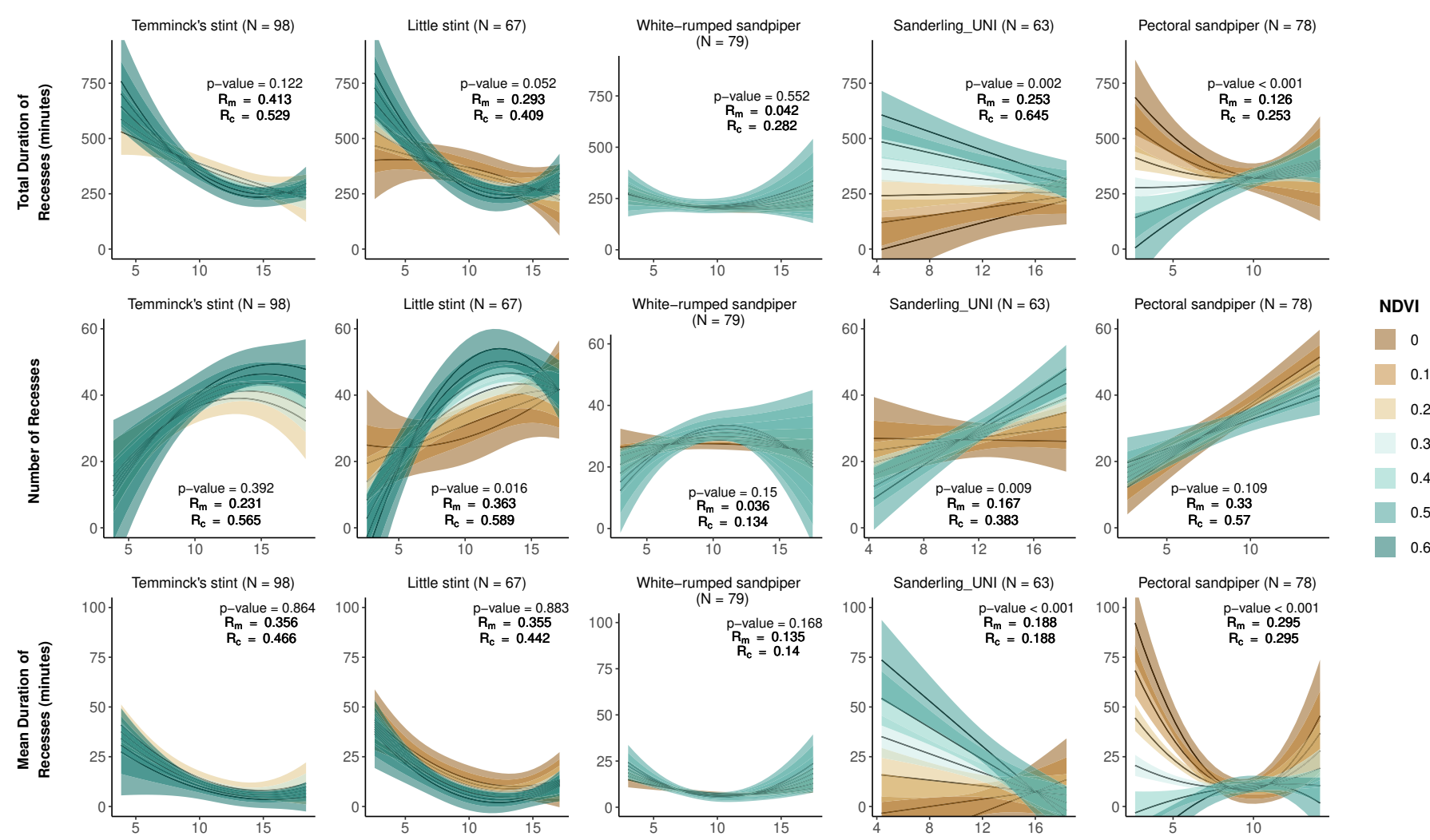

Daily average ground-surface temperature $\left({ }^{\circ} \mathrm{C}\right)$

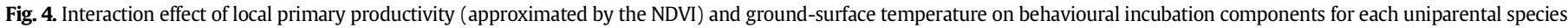

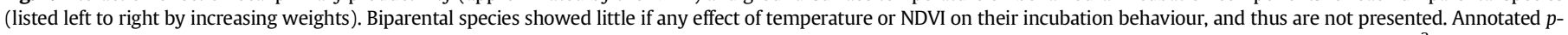

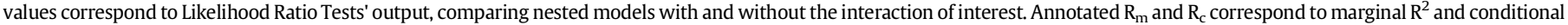
$\mathrm{R}^{2}$ respectively (i.e. coefficient of determination for linear mixed models; Nakagawa and Schielzeth, 2017). Shaded areas represent 95\% confidence intervals.

when the temperature was low, uniparental sanderlings took more but shorter recesses and were more attentive under low as compared to high productivity conditions (TDR: $\chi_{1}^{2}=9.7, p=0.002$; NR: $\chi_{1}^{2}=6.8$, $p=0.009$; MDR: $\chi_{1}^{2}=11.0, p=0.001$; Fig. 4).

We found that the relationships between ground-surface temperature and incubation behaviour components significantly varied with the average temperature of the previous day for some uniparental species only (i.e. significant lag effect; Fig. 5). For example, little stint took more recesses when the current day's ground-surface temperatures were at intermediate values and the previous day was cold as compared to when the previous day was warm. However, these relationships were reversed when the current ground-surface temperature was high, with little stint taking fewer and longer recesses when the previous day was cold as compared to when the previous day was warm (NR: $\chi_{2}^{2}=10.2$ $p=0.006$, MDR: $\chi_{2}^{2}=7.26 p=0.027$; Fig. 5). Comparatively, when the current day was cold, white-rumped sandpiper showed a strong relationship between their incubation behaviour and previous conditions with a higher nest attentiveness, more and shorter recesses after a warm day than after a cold day, whereas the effect of past conditions was reduced when the current day was warm (TDR: $\chi_{2}^{2}=18.1$ $\mathrm{p}<0.001$; NR: $\chi_{2}^{2}=34.1, \mathrm{p}<0.001$; MDR: $\chi_{2}^{2}=68.4, \mathrm{p}<0.001$; Fig. 5). Neither uniparental sanderlings, nor pectoral sandpipers, showed significant relationships involving past conditions.

\section{Discussion}

We found that the relationship between incubation behaviour and ground-surface temperature varied across nine Calidris species with different incubation strategies. As expected, we did not detect significant relationships between ground-surface temperature and components of incubation behaviour in most biparental species, whereas we did for all uniparental species. Although there was high interspecific variability among uniparental species, we found consistent negative relationships between total duration of recesses, mean duration of recesses and ground-surface temperature, as well as positive relationships between number of recesses and temperature. Moreover, most uniparental species showed non-linear relationships (as found for passerines; Morton and Pereyra, 1985; White and Kinney, 1974) with decreasing slopes (in absolute value) as ground-surface temperatures increased (except for uniparental sanderlings). In this study, we also showed that relationships between incubation behaviour and NDVI, which was used as a proxy for secondary productivity (i.e., arthropods), differed between incubation strategies (significant for total duration of recesses and number of recesses). However, the lack of significant relationships among all species prevented us from describing a general pattern for each strategy. We also found that relationships between incubation behaviour components and the groundsurface temperature could vary with productivity for some uniparental species. Finally, we found evidence that some uniparental species exposed to harsher temperatures appeared to adjust their subsequent incubation behaviour to recover their reserves.

We found that uniparental species took longer but less frequent recesses when ground-surface temperatures were low as reported in earlier studies (Cantar and Montgomerie, 1985; Cartar and Montgomerie, 1987; Norton, 1972; Tulp and Schekkerman, 2006; but see Reneerkens et al., 2011; and Smith et al., 2012a). During cold weather, it appears that adults are energetically constrained as both the amount of resources needed (i.e. increased energy expenditure; Cresswell et al., 

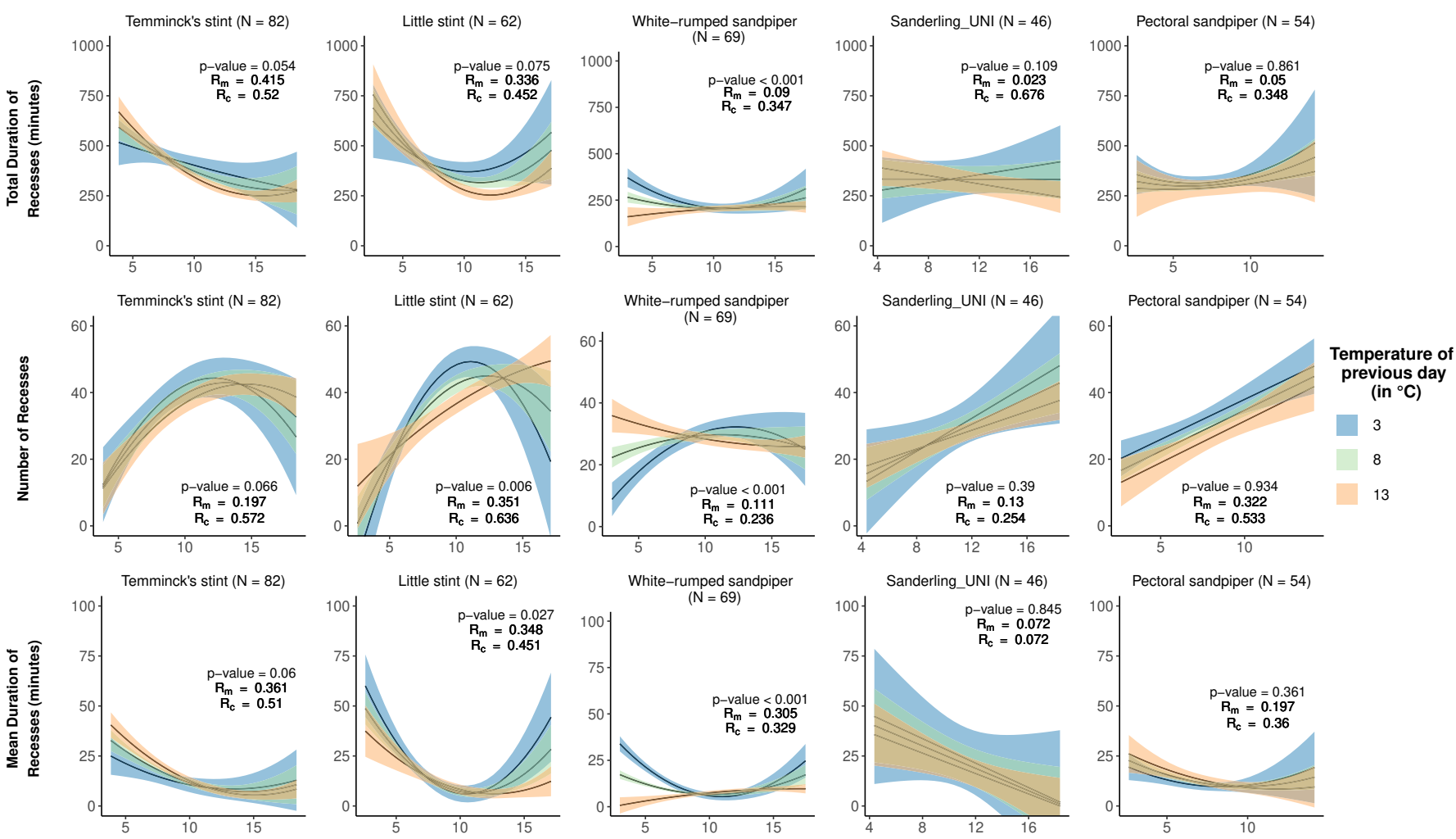

Daily average ground-surface temperature $\left({ }^{\circ} \mathrm{C}\right)$

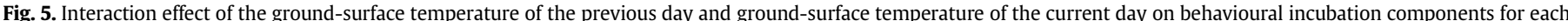

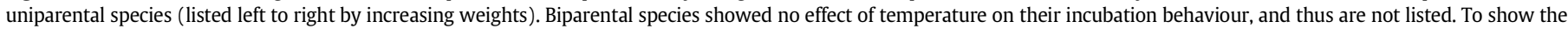

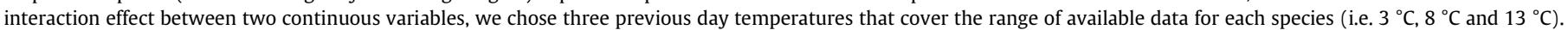

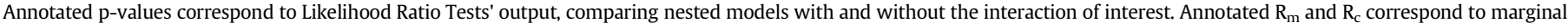
$\mathrm{R}^{2}$ and conditional $\mathrm{R}^{2}$ respectively (i.e. coefficient of determination for linear mixed models; Nakagawa and Schielzeth, 2017). Shaded areas represent $95 \%$ confidence interval.

2004; Tinbergen and Williams, 2002) and the time required to acquire those resources (i.e. low arthropod availability; Schekkerman et al., 2003) increases with declining temperatures. Consequently, adults spend more time foraging and less time incubating. However, we could have expected adults to decrease recess length in cold conditions (as observed for passerines; Conway and Martin, 2000b; Haftorn, 1988; White and Kinney, 1974) to keep their eggs' temperature from dropping too low and to reduce the time and energy needed to rewarm them (Biebach, 1986; Conway and Martin, 2000b). Indeed, exposing eggs to cold temperatures slows down the development of the embryos (Martin et al., 2007; Olson et al., 2006; Webb, 1987), negatively affects the growth of later-hatched chicks (Olson et al., 2006; Schekkerman et al., 2003), and has irreversible effect on their phenotype (e.g. immunocompetence DuRant et al., 2012; locomotor performance Hopkins et al., 2011; reviewed in DuRant et al., 2013). Spending more time foraging can also increase the risk of nest predation due to lower attentiveness and to a lengthening of the incubation period (Bosque and Bosque, 1995; Fontaine and Martin, 2006; Meyer et al., 2020; Tombre and Erikstad, 1996).

Several mechanisms may explain why adults benefit from longer recesses. First, in cold conditions, egg temperature may quickly reach the temperature at the ground surface and adults may save energy in rewarming their eggs less often (i.e., unless the temperature reaches a given threshold when it becomes lethal for the eggs). Second, adults may need more time to travel to areas with higher prey availability to increase food intake (provided that these areas differ from their preferred nesting habitat; Smith et al., 2007) and may therefore decrease the number of recesses to avoid additional locomotion costs (Kacelnik, 1984). Other authors also reported unusually long recesses (i.e. longer than 20 min in Tulp and Schekkerman, 2006) during cold spells (also referred as "egg neglect" in Smith et al., 2012a) that might have resulted from a low foraging efficiency in a situation of energy shortage (Haftorn, 1988; Morton and Pereyra, 1985; Smith et al., 2012a; Tulp and Schekkerman, 2006). Consequently, in warmer conditions, when arthropod prey is more abundant, adults save energy and increase their current reproductive success by performing frequent short recesses, preventing the temperature of their eggs from dropping too low while optimizing food intake (Haftorn, 1988; Vleck, 1981).

In contrast, adults of biparental species alternate at the nest and benefit from more time to forage during the partner's incubation bouts (Bulla et al., 2014), regardless of the current weather conditions (Norton, 1972; Reneerkens et al., 2011; present study). Yet, in cold conditions, basal metabolism and incubation costs also increase for biparental species, and parents are expected to alternate more often at the nest, reducing the duration of individual incubation bouts (Cresswell et al., 2003; but see Bulla et al., 2015) and potentially increasing the number of exchange gaps. In the present study, only Baird's sandpiper appeared to supports this statement as they showed an increased number of recesses in colder conditions, attributable either to an increased number of exchanges at the nest or to an increase in the number of individual recesses.

The interaction effect of the NDVI and ground-surface temperature was not uniform across uniparental species. For example, higher NDVI scores were related to fewer recesses at low ground-surface temperature and more recesses at medium ground-surface temperature in little stints. This is consistent with the idea that arthropod availability, that is related to both NDVI and daily temperature, is positively related to foraging efficiency in this species: adults find food quicker and take more 
recesses when conditions are productive and when temperatures allow arthropods to be active (Carey, 1980). In our study, only the pectoral sandpiper maintained high nest attentiveness under cold groundsurface conditions and high NDVI by taking short recesses, but behaved similarly to other species under equally cold conditions when NDVI was low. Hence, higher productivity may also favour a better overall adult body condition allowing adults to sustain a higher parental effort during cold spells to protect their eggs (Carey, 1980). The importance of food availability on nest attendance has also been shown in studies on female-incubating passerine species that display mate feeding (not observed in Calidris species). In this system, females that normally decrease their attentiveness in cold conditions were shown to maintain a higher attentiveness when food was provided by males (Pearse et al., 2004; Smith et al., 1989). Moreover, males were shown to deliver more food in cold conditions (Hałupka, 1994; Nilsson and Smith, 1988; Smith et al., 1989), allowing females to increase their nest attentiveness and thereby enhance the male's reproductive success (Lyon and Montgomerie, 1985). Conversely, uniparental sanderlings did not support this hypothesis (i.e. higher productivity favours greater nest attentiveness with more and shorter recesses); higher productivity was related to decreased parental care (i.e. a lower attentiveness with longer recesses). However, sanderling have a mixed incubation strategy and uniparental sanderling may not behave the same as an obligatory uniparental species during incubation (i.e., they can compensate after their partner's desertion). Finally, vegetation cover, which contributes to NDVI, can also increase nest concealment and insulation for species nesting in densely vegetated areas, which may ultimately affect their incubation behaviour (Reid et al., 2002).

If incubation strategy modulates the trade-off between incubation and foraging, the relationship between incubation behaviour and environmental conditions might also vary across uniparental species due to different life-history traits (e.g. body size or nesting habitat). Indeed, we found two "groups" among uniparental species: the little and Temminck's stints that had a strong relationship between incubation behaviour and temperature, and the white-rumped sandpipers and uniparental sanderlings that showed weaker relationships. Interestingly, pectoral sandpipers could not be distinguished from any other uniparental species regarding these relationships, but the study of the vertex provided additional insights. Indeed, pectoral and white-rumped sandpipers appeared to show a lower sensitivity (i.e. lower vertex) to temperature than little and Temminck's stints, while the latter two species also showed a lower attentiveness and longer recesses compared to all other species in cold conditions (see also Fig. 2 in Meyer et al., 2020). These differences might be related to the smaller size of both stints species (15-44 g), compared to larger white-rumped sandpiper females (30-60 g), pectoral sandpiper females (31-97 g) and sanderlings (33-110 g) (Del Hoyo et al., 1996). Hence, these results suggest that large uniparental species can sustain a higher attentiveness and are less sensitive to cold environmental temperatures than smaller uniparental species (Tulp and Schekkerman, 2006). Indeed, size and weight are good proxies for the physiological ability of a species to build and maintain body reserves, and they also correlate with heat loss of adults (i.e. smaller species lose heat faster; Morrison and Hobson, 2004; Piersma et al., 2003; Schamel and Tracy, 1987).

Like other long-distance migratory shorebirds, Calidris species store energy (Piersma and Lindström, 1997) that may help them cope with future unpredictable energetic challenges. After egg-laying, such reserves may represent an "energetic insurance" to enable consistent incubation behaviour under unpredictable conditions (Soloviev and Tomkovich, 1997; Tulp et al., 2002; Tulp and Schekkerman, 2006). Hence, incubation behaviour varies with current conditions but may also vary due to the way past decisions have affected body reserves through a lag effect ("historical factor"; Cartar and Montgomerie, 1987). Here, we found that little stints and to a lesser extent Temminck's stints showed lower nest attentiveness (less and longer recesses) even though a day was warm if they had experienced colder conditions during the previous day. When prior day was warm this pattern went away. We can therefore hypothesize that little and Temminck's stints that lose weight during a cold day will compensate for store depletion by foraging more in subsequent days. Tulp et al. (2002) also found that adults who lost weight during cold spells were able to recover when conditions improved, hence maintaining a consistent body mass throughout incubation. We also found that female white-rumped sandpipers were able to maintain higher nest attentiveness with more frequent and shorter recesses in cold conditions when the previous day was warm. We hence assume that energy stored during a warm day can also allow some Calidris species to increase parental effort during future bad conditions.

The entire community of arctic terrestrial vertebrates is currently experiencing seasonal and long-term changes in environmental conditions driven by climate change (Gilg et al., 2009, 2012; Ims and Fuglei, 2005; Post et al., 2009; Saalfeld et al., 2019; Schmidt et al., 2017). In this context, we present new insights into the effects of groundsurface temperature and site productivity, which closely track climate change (Stow et al., 2004; Tape et al., 2006), on the incubation behaviour of ground nesting shorebirds. Although predation, rather than abiotic conditions or a parent's body resources, is often considered to be the main cause of reproductive failure in birds (Martin, 1993; Reneerkens et al., 2016; Ricklefs, 1969; Skutch, 1949; Smith et al., 2007), several studies also indicate incubation behaviour can affect the risk of nest predation (e.g., a negative relationship between nest attentiveness and the daily predation rate; Meyer et al., 2020; Smith et al., 2012b). Understanding how birds adjust their behaviour under changing abiotic conditions and, in turn, how these behavioural changes impact predation risk, will greatly help us to predict the future population dynamics of arctic nesting species.

\section{CRediT authorship contribution statement}

NM, LB, JM and OG conceived the ideas and designed methodology, with substantial contribution from MG;

All co-authors participated substantially to the data collection and/ or contributed critically to the drafts;

NM and MG analyzed the data;

NM, LB and OG led the writing of the manuscript;

All co-authors gave final approval for publication.

\section{Declaration of competing interest}

The authors declare that they have no known competing financial interests or personal relationships that could have appeared to influence the work reported in this paper.

\section{Acknowledgements}

We are particularly grateful to all people who helped collect the field data used in this study within the frame of the "Interactions Working Group": Vadim Heuacker (HOCH, SABE), Eric Buchel (HOCH), Jasper Koster (ERKU, HOCH), Ivan Fufachev (ERKU, SABE), Don-Jean LéandriBreton (BYLO, SABE), Laurent Demongin (SABE), Aurélie ChagnonLafortune (BYLO), Éliane Duchesne (BYLO), Tom Versluijs (ZACK), Marleen Eikelenboom (ZACK), Palle Smedegaard Nielsen (ZACK), Leah Wright (CHUR), Victor Olek (CHUR), Kerrith McKay (CHUR), Taylor Brown (CHUR), Felix Normann (KVPE), Philipp Weiner (KVPE), Sven Büchner (KVPE), Laurent Montagno (IGLO), Marianne Gousy-Leblanc (IGLO), Audrey Bédard (IGLO), Sarah Jacques (IGLO), Sylvain Christin (IGLO), Tommy O'Neil Sanger (IGLO), Mathieu Archambault (IGLO), Alexandra Gagnon (IGLO), Arian Reda (IGLO), Jacinthe Gosselin (IGLO), Kim Regimbald-Bélanger (IGLO), Laurence Carter (IGLO), Lindsay Gauvin (IGLO), Tim van der Meer (AMMA), Christian Hoefs (AMMA), Michiel Elderenbosch (AMMA), Peter Antkowiak (AMMA), Morrison Pot (AMMA), Birgith Underthurner (AMMA), Therese Flink (AMMA), 
Willow English (UTQI), Ben Lagasse (UTQI), Wyatt Egelhoff (UTQI), Lindsay Hermanns (UTQI), Jillian Cosgrove (UTQI), Laura Makielski (UTQI and CARI), Elyssa Watford (CARI), Shiloh Schulte (CARI), Makenna Fair (CARI), Shilo Felton (CARI), Sarah Hoepfner (CARI), Aaron Yappert (CARI), Samuel Vasfsallo (CARI), Timothy Knudson (CARI), Kim Bennett (BURN), Rod Brook (BURN), Lisa Pollock (BURN) and Christian Stolz (LONG).

This study was supported by the French Polar Institute (program "1036 Interactions"), PRC CNRS Russie (program "ECCVAT"; SABE and ERKU), the Natural Sciences and Engineering Research Council of Canada (NSERC; IGLO, BYLO), the Polar Continental Shelf Program (IGLO, BYLO), the Canada Chair Research Program (IGLO), the Canadian Fund for Innovation (IGLO), Northern Scientific Training Program (BYLO, IGLO and CHUR), the Igloolik Hunters and Trappers Organization (IGLO), Université de Moncton (IGLO), ArcticNet (BYLO), Polar Knowledge Canada (BYLO), the Churchill Northern Studies Centre (CHUR), the Russian Fund for Basic Research (grants \#18-54-15013 and \#1805-60261; ERKU, SABE, BELY), Yamal-LNG (SABE), Gazpromtrans (ERKU), NGO Russian Center of Development of the Arctic (ERKU), the Netherlands Polar Program of the Netherlands Organization for Scientific research (grant \#866.15.207 and \#886.13.005; ZACK and AMMA), the Danish Environmental Protection Agency (ZACK), the Metawad project awarded by Waddenfonds (WF209925; ZACK), U.S. Fish and Wildlife Service (UTQI and CARI), Arctic Landscape Conservation Cooperative (UTQI), the National Fish and Wildlife Foundation (UTQI), Manomet Inc (UTQI, CARI), Alaska Cooperative Fish and Wildlife Research Unit (CARI), and The University Centre in Svalbard (UNIS).

\section{Appendix A. Supplementary data}

Supplementary data to this article can be found online at https://doi. org/10.1016/j.scitotenv.2020.142485.

\section{References}

Alerstam, T., Hedenström, A., Åkesson, S., 2003. Long-distance migration: evolution and determinants. Oikos 103, 247-260. https://doi.org/10.1034/j.16000706.2003.12559.x.

Ashkenazie, S., Safriel, U.N., 1979. Breeding cycle and behavior of the semipalmated sandpiper at Barrow, Alaska. Auk 96, 56-67.

Biebach, H., 1986. Energetics of rewarming a clutch in starlings (Sturnus vulgaris). Physiol. Zool. 59, 69-75. https://doi.org/10.1086/physzool.59.1.30156092.

Bolduc, E., Casajus, N., Legagneux, P., McKinnon, L., Gilchrist, H.G., Leung, M., Morrison, R.I.G., Reid, D., Smith, P.A., Buddle, C.M., Bêty, J., 2013. Terrestrial arthropod abundance and phenology in the Canadian Arctic: modelling resource availability for Arctic-nesting insectivorous birds. The Canadian Entomologist 145, 155-170. https://doi.org/10.4039/tce.2013.4.

Bosque, C., Bosque, M.T., 1995. Nest predation as a selective factor in the evolution of developmental rates in altricial birds. Am. Nat. 145, 234-260. https://doi.org/10.1086/ 285738.

Brown, M., Downs, C.T., 2003. The role of shading behaviour in the thermoregulation of breeding crowned plovers (Vanellus coronatus). J. Therm. Biol. 28, 51-58. https:// doi.org/10.1016/S0306-4565(02)00036-0.

Bulla, M., Valcu, M., Rutten, A., Kempenaers, B., 2014. Biparental incubation patterns in a high-Arctic breeding shorebird: how do pairs divide their duties? Behav. Ecol. 25, 152-164. https://doi.org/10.1093/beheco/art098.

Bulla, M., Cresswell, W., Rutten, A.L., Valcu, M., Kempenaers, B., 2015. Biparental incubation-scheduling: no experimental evidence for major energetic constraints. Behav. Ecol. 26, 30-37. https://doi.org/10.1093/beheco/aru156.

Bulla, M., Valcu, M., Dokter, A.M., Dondua, A.G., Kosztolányi, A., Rutten, A.L., Helm, B., Sandercock, B.K., Casler, B., Ens, B.J., Spiegel, C.S., Hassell, C.J., Küpper, C., Minton, C., Burgas, D., Lank, D.B., Payer, D.C., Loktionov, E.Y., Nol, E., Kwon, E., Smith, F., Gates, H.R., Vitnerová, H., Prüter, H., Johnson, J.A., St Clair, J.J.H., Lamarre, J.-F., Rausch, J., Reneerkens, J., Conklin, J.R., Burger, J., Liebezeit, J., Bêty, J., Coleman, J.T., Figuerola, J., Hooijmeijer, J.C.E.W., Alves, J.A., Smith, J.A.M., Weidinger, K., Koivula, K., Gosbell, K. Exo, K.-M., Niles, L., Koloski, L., McKinnon, L., Praus, L., Klaassen, M., Giroux, M.-A., Sládeček, M., Boldenow, M.L., Goldstein, M.I., Šálek, M., Senner, N., Rönkä, N., Lecomte, N., Gilg, O., Vincze, O., Johnson, O.W., Smith, P.A., Woodard, P.F., Tomkovich, P.S., Battley, P.F., Bentzen, R., Lanctot, R.B., Porter, R., Saalfeld, S.T. Freeman, S., Brown, S.C., Yezerinac, S., Székely, T., Montalvo, T., Piersma, T., Loverti, V., Pakanen, V.-M., Tijsen, W., Kempenaers, B., 2016. Unexpected diversity in socially synchronized rhythms of shorebirds. Nature 540, 109-113. https://doi.org/10.1038/ nature20563.

Bulla, M., Prüter, H., Vitnerová, H., Tijsen, W., Sládeček, M., Alves, J., Gilg, O., Kempenaers, B., 2017. Flexible parental care: Uniparental incubation in biparentally incubating shorebirds. Sci. Rep. 7. https://doi.org/10.1038/s41598-017-13005-y.
Bulla, M., Reneerkens, J., Weiser, E.L., Sokolov, A., Taylor, A.R., Sittler, B., McCaffery, B.J. Ruthrauff, D.R., Catlin, D.H., Payer, D.C., Ward, D.H., Solovyeva, D.V., Santos, E.S.A., Rakhimberdiev, E., Nol, E., Kwon, E., Brown, G.S., Hevia, G.D., Gates, H.R., Johnson, J.A., van Gils, J.A., Hansen, J., Lamarre, J.-F., Rausch, J., Conklin, J.R., Liebezeit, J., Bêty, J., Lang, J., Alves, J.A., Fernández-Elipe, J., Exo, K.-M., Bollache, L., Bertellotti, M., Giroux, M.-A., van de Pol, M., Johnson, M., Boldenow, M.L., Valcu, M., Soloviev, M.Y., Sokolova, N., Senner, N.R., Lecomte, N., Meyer, N., Schmidt, N.M., Gilg, O., Smith, P.A. Machín, P., McGuire, R.L., Cerboncini, R.A.S., Ottvall, R., van Bemmelen, R.S.A., Swift, R.J., Saalfeld, S.T., Jamieson, S.E., Brown, S., Piersma, T., Albrecht, T., D’Amico, V., Lanctot, R.B., Kempenaers, B., 2019. Comment on "Global pattern of nest predation is disrupted by climate change in shorebirds". Science 364, eaaw8529. https://doi. org/10.1126/science.aaw8529.

Burnham, K.P., Anderson, D.R., 2004. Multimodel inference: understanding AIC and BIC in model selection. Sociol. Methods Res. 33, 261-304. https://doi.org/10.1177/ 0049124104268644.

Cantar, R.V., Montgomerie, R.D., 1985. The influence of weather on Incubation scheduling of the white-rumped sandpiper (Calidris Fuscicollis): a uniparental incubator in a cold environment. Behaviour 95, 261-289. https://doi.org/10.1163/156853985X00154.

Carey, C., 1980. The ecology of avian incubation. BioScience 30, 819-824. https://doi.org/ $10.2307 / 1308374$.

Cartar, R.V., Montgomerie, R.D., 1987. Day-to-day variation in nest attentiveness of whiterumped sandpipers. Condor 89, 252-260. https://doi.org/10.2307/1368478.

Chalfoun, A.D., Martin, T.E., 2007. Latitudinal variation in avian incubation attentiveness and a test of the food limitation hypothesis. Anim. Behav. 73, 579-585. https://doi. org/10.1016/j.anbehav.2006.09.010.

Conway, C.J., Martin, T.E., 2000a. Evolution of passerine Incubation behavior: influence of food, temperature, and nest predation. Evolution 54, 670-685. https://doi.org/ 10.1111/j.0014-3820.2000.tb00068.x.

Conway, C.J., Martin, T.E., 2000b. Effects of ambient temperature on avian incuation behavior. Behav. Ecol. 11, 178-188. https://doi.org/10.1093/beheco/11.2.178.

R Core Team, 2019. R: A Language and Environment for Statistical Computing. R Foundation for Statistical Computing, Vienna, Austria.

Cramp, S., Simmons, K., 1983. Waders to Gulls, the Birds of the Western Palearctic. Oxford University Press, Oxford.

Cresswell, W., Holt, S., Reid, J.M., Whitfield, D.P., Mellanby, R.J., 2003. Do energetic demands constrain incubation scheduling in a biparental species? Behav. Ecol. 14, 97-102. https://doi.org/10.1093/beheco/14.1.97.

Cresswell, W., Holt, S., Reid, J.M., Whitfield, D.P., Mellanby, R.J., Norton, D., Waldron, S., 2004. The energetic costs of egg heating constrain incubation attendance but do not determine daily energy expenditure in the pectoral sandpiper. Behav. Ecol. 15, 498-507. https://doi.org/10.1093/beheco/arh042.

Danks, H.V., 1999. Life cycles in polar arthropods - flexible or programmed? EJE 96, 83-102.

Deeming, D.C., 2002. Importance and evolution of incubation in avian reproduction. In: Incubation, Avian (Ed.), Behaviour. Environment and Evolution. D.C. Deeming, Oxford, pp. 314-321.

Del Hoyo, J., Elliott, A., Sargatal, J., 1996. Hoatzin to Auks, Handbook of the Birds of the World. Lynx Edicions, Barcelona.

Didan, K., Munoz, A.B., Solano, R., Huete, A., 2015. MODIS Vegetation Index User's Guide (MOD13 Series). The University of Arizona, Tucson, Arizona.

Drent, R.H., Daan, S., 1980. The prudent parent: energetic adjustments in avian breeding. Ardea 38-90, 225-252. https://doi.org/10.5253/arde.v68.p225.

DuRant, S.E., Hopkins, W.A., Hawley, D.M., Hepp, G.R., 2012. Incubation temperature affects multiple measures of immunocompetence in young wood ducks (Aix Sponsa). Biol. Lett. 8, 108-111. https://doi.org/10.1098/rsbl.2011.0735.

DuRant, S.E., Hopkins, W.A., Hepp, G.R., Walters, J.R., 2013. Ecological, evolutionary, and conservation implications of incubation temperature-dependent phenotypes in birds. Biol. Rev. 88, 499-509. https://doi.org/10.1111/brv.12015.

Fontaine, J.J., Martin, T.E., 2006. Habitat selection responses of parents to offspring predation risk: an experimental test. Am. Nat. 168, 811-818. https://doi.org/10.1086/ 508297.

Ghalambor, C.K., Martin, T.E., 2002. Comparative manipulation of predation risk in incubating birds reveals variability in the plasticity of responses. Behav. Ecol. 13, 101-108. https://doi.org/10.1093/beheco/13.1.101.

Gilg, O., Yoccoz, N.G., 2010. Explaining bird migration. Science 327, 276-277. https://doi. org/10.1126/science.1184964

Gilg, O., Sittler, B., Hanski, I., 2009. Climate change and cyclic predator-prey population dynamics in the high Arctic. Glob. Chang. Biol. 15, 1634-2652. https://doi.org/ 10.1111/j.1365-2486.2009.01927.x.

Gilg, O., Kovacs, K.M., Aars, J., Fort, J., Gauthier, G., Grémillet, D., Ims, R.A., Meltofte, H., Moreau, J., Post, E., Schmidt, N.M., Yannic, G., Bollache, L., 2012. Climate change and the ecology and evolution of Arctic vertebrates. Ann. N. Y. Acad. Sci. 1249, 166-190. https://doi.org/10.1111/j.1749-6632.2011.06412.x.

Gill, J., Tomkovich, P. Robert, 2004. Subarctic, alpine nesting by Baird's sandpipers Calidris bairdii. Wader Study Group Bull. 104, 39-50.

Haftorn, S., 1988. Incubating female passerines do not let the egg temperature fall below the "physiological zero temperature" during their absences from the Nest. Ornis Scandinavica (Scandinavian Journal of Ornithology) 19, 97-110. https://doi.org/ $10.2307 / 3676458$.

Hałupka, K., 1994. Incubation feeding in meadow pipit Anthus pratensis affects female time budget. J. Avian Biol. 25, 251-253. https://doi.org/10.2307/3677083.

Hansen, J., Schmidt, N.M., Reneerkens, J., 2011. Egg hatchability in high Arctic breeding wader species Charadriiformes is not affected by determining incubation stage using the egg flotation technique. Bird Study 58, 522-525. https://doi.org/10.1080/ 00063657.2011.601411. 
Hildén, O., 1975. Breeding system of Temminck's stint Calidris temminckii. Ornis 52, $117-146$

Hodkinson, I.D., Coulson, S.J., Webb, N.R., Block, W., Strathdee, A.T., Bale, J.S., Worland, M.R., 1996. Temperature and the biomass of flying midges (Diptera: Chironomidae) in the High Arctic. Oikos 75, 241-248. https://doi.org/10.2307/3546247.

Holmes, R.T., 1966. Breeding ecology and annual cycle adaptations of the red-backed sandpiper (Calidris alpina) in northern Alaska. Condor 68, 3-46. https://doi.org/ 10.2307/1365173.

Hopkins, B.C., DuRant, S.E., Hepp, G.R., Hopkins, W.A., 2011. Incubation temperature influences locomotor performance in young wood ducks (Aix sponsa). J. Exp. Zool. A Ecol. Genet. Physiol. 315A, 274-279. https://doi.org/10.1002/jez.673.

Høye, T.T., Forchhammer, M.C., 2008. The influence of weather conditions on the activity of high-arctic arthropods inferred from long-term observations. BMC Ecol. 8, 8. https://doi.org/10.1186/1472-6785-8-8.

Ims, R.A., Fuglei, E., 2005. Trophic interaction cycles in tundra ecosystems and the impact of climate change. BioScience 55, 311-322. https://doi.org/10.1641/0006-3568 (2005)055[0311:TICITE]2.0.CO;2.

Jia, G.J., Epstein, H.E., Walker, D.A., 2003. Greening of arctic Alaska, 1981-2001. Geophys. Res. Lett. 30. https://doi.org/10.1029/2003GL018268.

Kacelnik, A., 1984. Central place foraging in starlings (Sturnus vulgaris). I. Patch Residence Time. Journal of Animal Ecology 53, 283-299. https://doi.org/10.2307/4357.

Kerr, J.T., Ostrovsky, M., 2003. From space to species: ecological applications for remote sensing. Trends Ecol. Evol. 18, 299-305. https://doi.org/10.1016/S0169-5347(03) 00071-5.

Klaassen, M. 2003. Relationships between migration and breeding strategies in Arctic breeding birds. In: Berthold, P., Gwinner, E., Sonnenschein, E. (Eds.), Avian Migration. Springer, Berlin Heidelberg, pp. 237-249.

Klaassen, M., Lindström, Å., Meltofte, H., Piersma, T., 2001. Ornithology: Arctic waders are not capital breeders. Nature 413, 794. https://doi.org/10.1038/35101654.

Kwon, E., Weiser, E.L., Lanctot, R.B., Brown, S.C., Gates, H.R., Gilchrist, G., Kendall, S.J., Lank, D.B., Liebezeit, J.R., McKinnon, L., Nol, E., Payer, D.C., Rausch, J., Rinella, DJ., Saalfeld, S.T., Senner, N.R., Smith, P.A., Ward, D., Wisseman, R.W., Sandercock, B.K., 2019. Geographic variation in the intensity of warming and phenological mismatch between Arctic shorebirds and invertebrates. Ecol. Monogr. 89, e01383. https://doi.org/ 10.1002/ecm.1383.

Lassau, S.A., Hochuli, D.F., 2008. Testing predictions of beetle community patterns derived empirically using remote sensing. Divers. Distrib. 14, 138-147. https://doi.org/ 10.1111/j.1472-4642.2007.00438.x.

Liebezeit, J.R., Smith, P.A., Lanctot, R.B., Schekkerman, H., Tulp, I., Kendall, S.J., Tracy, D.M., Rodrigues, R.J., Meltofte, H., Robinson, J.A., Gratto-Trevor, C., Mccaffery, B.J., Morse, J., Zack, S.W., 2007. Assessing the development of shorebird eggs using the flotation method: species-specific and generalized regression models. Condor 109, 32-47. https://doi.org/10.1650/0010-5422(2007)109[32:ATDOSE]2.0.CO;2.

Londono, G.A., Levey, D.J., Robinson, S.K., 2008. Effects of temperature and food on incubation behaviour of the northern mockingbird, Mimus polyglottos. Anim. Behav. 76, 669-677. https://doi.org/10.1016/j.anbehav.2008.05.002.

Lyon, B.E., Montgomerie, R.D., 1985. Incubation feeding in snow buntings: female manipulation or indirect male parental care? Behav. Ecol. Sociobiol. 17, 279-284. https:// doi.org/10.1007/BF00300147.

Mabee, T.J., Wildman, A.M., Johnson, C.B., 2006. Using egg flotation and eggshell evidence to determine age and fate of Arctic shorebird nests. Journal of Field Ornithology 77, 163-172. https://doi.org/10.1111/j.1557-9263.2006.00037.x.

Martin, T.E., 1993. Nest predation among vegetation layers and habitat types: revising the dogmas. Am. Nat. 141, 897-913. https://doi.org/10.1086/285515.

Martin, K., Wiebe, K.L., 2004. Coping mechanisms of alpine and Arctic breeding birds: extreme weather and limitations to reproductive resilience. Integr. Comp. Biol. 44, 177-185. https://doi.org/10.1093/icb/44.2.177.

Martin, T.E., Auer, S.K., Bassar, R.D., Niklison, A.M., Lloyd, P., 2007. Geographic variation in avian Incubation periods and parental influences on embryonic temperature. Evolution 61, 2558-2569. https://doi.org/10.1111/j.1558-5646.2007.00204.x.

Mayfield, H.F., 1978. Undependable breeding conditions in the red phalarope. Auk 95 , 590-592.

McKinnon, L., Smith, P.A., Nol, E., Martin, J.L., Doyle, F.I., Abraham, K.F., Gilchrist, H.G., Morrison, R.I.G., Bêty, J., 2010. Lower predation risk for migratory birds at high latitudes. Science 327, 326-327. https://doi.org/10.1126/science.1183010.

McKinnon, L., Nol, E., Juillet, C., 2013. Arctic-nesting birds find physiological relief in the face of trophic constraints. Sci. Rep. 3, 1816. https://doi.org/10.1038/srep01816.

McNamara, J.M., Houston, A.I., 1996. State-dependent life histories. Nature 380, 215. https://doi.org/10.1038/380215a0.

McNamara, J.M., Houston, A.I., Lima, S.L., 1994. Foraging routines of small birds in winter: a theoretical investigation. J. Avian Biol. 25, 287-302. https://doi.org/10.2307/ 3677276

Meltofte, H., Høye, T.T., Schmidt, N.M., Forchhammer, M.C., 2007. Differences in food abundance cause inter-annual variation in the breeding phenology of High Arctic waders. Polar Biol. 30, 601. https://doi.org/10.1007/s00300-006-0219-1.

Meyer, N., Bollache, L., Dechaume-Moncharmont, F.-X., Moreau, J., Afonso, E., Angerbjörn, A., Bêty, J., Ehrich, D., Gilg, V., Giroux, M.-A., Hansen, J., Lanctot, R.B., Lang, J., Lecomte, N., McKinnon, L., Reneerkens, J., Saalfeld, S.T., Sabard, B., Schmidt, N.M., Sittler, B., Smith, P., Sokolov, A., Sokolov, V., Sokolova, N., van Bemmelen, R., Gilg, O., 2020. Nest attentiveness drives nest predation in arctic sandpipers. Oikos n/a. https://doi. org/10.1111/oik.07311.

Moreau, J., Perroud, L., Bollache, L., Yannic, G., Teixeira, M., Schmidt, N.M., Reneerkens, J., Gilg, O., 2018. Discriminating uniparental and biparental breeding strategies by monitoring nest temperature. Ibis 160, 13-22. https://doi.org/10.1111/ibi.12507.
Morrison, R.I. Hobson, K.A., 2004. Use of body stores in shorebirds after arrival on higharctic breeding grounds. Auk 121, 333-344. https://doi.org/10.1642/0004-8038 (2004)121[0333:UOBSIS]2.0.CO;2.

Morton, M.L., Pereyra, M.E., 1985. The regulation of egg temperatures and attentiveness patterns in the dusky flycatcher (Empidonax oberholseri). Auk 102, 25-37. https:// doi.org/10.2307/4086819.

Nakagawa, S., Schielzeth, H., 2017. A general and simple method for obtaining R2 from generalized linear mixed-effects models. Methods in Ecology and Evolution, 133-142 https://doi.org/10.1111/j.2041-210x.2012.00261.x@10.1111/(ISSN)2041210X.STATSTOO.

Neigh, C., Tucker, C., Townshend, J., 2008. North American vegetation dynamics observed with multi-resolution satellite data. Remote Sens. Environ. 112, 1749-1772. https:// doi.org/10.1016/j.rse.2007.08.018.

Nilsson, J.-Å., Smith, H.G., 1988. Incubation feeding as a male tactic for early hatching Anim. Behav. 36, 641-647. https://doi.org/10.1016/S0003-3472(88)80145-3.

Norton, D.W., 1972. Incubation schedules of four species of calidridine sandpipers at Barrow, Alaska. Condor 74, 164-176. https://doi.org/10.2307/1366280.

Olson, C.R., Vleck, C.M., Vleck, D., 2006. Periodic cooling of bird eggs reduces embryonic growth efficiency. Physiol. Biochem. Zool. 79, 927-936. https://doi.org/10.1086/ 506003.

Parmelee, D.F., Greiner, D.W., Graul, W.D., 1968. Summer schedule and breeding biology of the white-rumped sandpiper in the central Canadian arctic. The Wilson Bulletin $80,1-26$.

Pearse, A.T., Cavitt Jr., J.F., J.F.C, 2004. Effects of food supplementation on female nest attentiveness and incubation mate feeding in two sympatric wren species. wils. 1 (116), 23-30. https://doi.org/10.1676/0043-5643(2004)116[0023:EOFSOF]2.0.CO;2.

Pettorelli, N., Vik, J.O., Mysterud, A., Gaillard, J., Tucker, C.J., Stenseth, N.C., 2005. Using the satellite-derived NDVI to assess ecological responses to environmental change. Trends Ecol. Evol. 20, 503-510. https://doi.org/10.1016/j.tree.2005.05.011.

Pierce, E.P., 1997. Sex roles in the monogamous purple sandpiper Calidris maritima in Svalbard. Ibis 139, 159-169. https://doi.org/10.1111/j.1474-919X.1997.tb04516.x.

Piersma, T., 1997. Do global patterns of habitat use and migration strategies co-evolve with relative Investments in Immunocompetence due to spatial variation in parasite pressure? Oikos 80, 623-631. https://doi.org/10.2307/3546640.

Piersma, T., Lindström, Å., 1997. Rapid reversible changes in organ size as a component of adaptive behaviour. Trends Ecol. Evol. 12, 134-138. https://doi.org/10.1016/S01695347(97)01003-3.

Piersma, T., Morrison, R.I.G., 1994. Energy expenditure and water turnover of incubating ruddy turnstones: high costs under High Arctic climatic conditions. Auk 111, 366-376. https://doi.org/10.2307/4088600.

Piersma, T., Lindström, Å., Drent, R.H., Tulp, I., Jukema, J., Morrison, R.I.G., Reneerkens, J., Schekkerman, H., Visser, G.H., 2003. High daily energy expenditure of incubating shorebirds on High Arctic tundra: a circumpolar study. Funct. Ecol. 17, 356-362. https://doi.org/10.1046/j.1365-2435.2003.00741.x.

Pinheiro, J., Bates, D., DebRoy, S., Sarkar, D., Heisterkamp, S., Van Willigen, B., R-core, 2019. nlme: Linear and Nonlinear Mixed Effects Models.

Pitelka, F.A., Holmes, R.T., Maclean, S.F., 1974. Ecology and evolution of social organization in arctic sandpipers. Integr. Comp. Biol. 14, 185-204. https://doi.org/10.1093/icb/ 14.1 .185

Post, E., Forchhammer, M.C., Bret-Harte, M.S., Callaghan, T.V., Christensen, T.R., Elberling, B., Fox, A.D., Gilg, O., Hik, D.S., Høye, T.T., Ims, R.A., Jeppesen, E., Klein, D.R., Madsen, J., McGuire, A.D., Rysgaard, S., Schindler, D.E., Stirling, I., Tamstorf, M.P., Tyler, N.J.C., van der Wal, R., Welker, J., Wookey, P.A., Schmidt, N.M., Aastrup, P., 2009. Ecological dynamics across the Arctic associated with recent climate change. Science 325 , 1355-1358. https://doi.org/10.1126/science.1173113.

Raynolds, M.K., Walker, D.A., Maier, H.A., 2006. NDVI patterns and phytomass distribution in the circumpolar Arctic. Remote Sens. Environ. 102, 271-281. https://doi.org/ 10.1016/j.rse.2006.02.016.

Reed, B.C., Brown, J.F., VanderZee, D., Loveland, T.R., Merchant, J.W., Ohlen, D.O., 1994 Measuring phenological variability from satellite imagery. J. Veg. Sci. 5, 703-714. https://doi.org/10.2307/3235884.

Reid, J.M., Cresswell, W., Holt, S., Mellanby, R.J., Whitfield, D.P., Ruxton, G.D., 2002. Nest scrape design and clutch heat loss in pectoral sandpipers (Calidris melanotos). Funct. Ecol. 16, 305-312. https://doi.org/10.1046/j.1365-2435.2002.00632.x.

Reneerkens, J., Grond, K., Schekkerman, H., Tulp, I., Piersma, T., 2011. Do Uniparenta sanderlings Calidris alba increase egg heat input to compensate for low Nest attentiveness? PLoS One 6, e16834. https://doi.org/10.1371/journal.pone.0016834.

Reneerkens, J., van Veelen, P., van der Velde, M., Luttikhuizen, P., Piersma, T., 2014 Within-population variation in mating system and parental care patterns in the Sanderling (Calidris alba) in northeast Greenland. Auk 131, 235-247. https://doi. org/10.1642/AUK-13-247.1.

Reneerkens, J., Schmidt, N.M., Gilg, O., Hansen, J., Hansen, L.H., Moreau, J., Piersma, T. 2016. Effects of food abundance and early clutch predation on reproductive timing in a high Arctic shorebird exposed to advancements in arthropod abundance. Ecology and Evolution 6, 7375-7386. https://doi.org/10.1002/ece3.2361.

Reynolds, J.D., Székely, T., 1997. The evolution of parental care in shorebirds: life histories, ecology, and sexual selection. Behav. Ecol. 8, 126-134. https://doi.org/10.1093/ beheco/8.2.126.

Ricklefs, R.E., 1969. An analysis of nesting mortality in birds. Smithsonian Contributions to Zoology, 1-48 https://doi.org/10.5479/si.00810282.9.

Saalfeld, S.T., McEwen, D.C., Kesler, D.C., Butler, M.G., Cunningham, J.A., Doll, A.C., English, W.B., Gerik, D.E., Grond, K., Herzog P.. Hill, B.L., Lagassé, B.J. Lanctot, R.B., 2019. Phenological mismatch in Arctic-breeding shorebirds: impact of snowmelt and unpredictable weather conditions on food availability and chick growth. Ecology and Evolution 9, 6693-6707. https://doi.org/10.1002/ece3.5248. 
Schamel, D., Tracy, D.M., 1987. Latitudinal trends in breeding red phalaropes (Tendencias Latitudinales en la Reproducción de Phalaropus fulicaria). Journal of Field Ornithology 58, 126-134.

Schekkerman, H., Tulp, I., Piersma, T., Visser, G.H., 2003. Mechanisms promoting higher growth rate in arctic than in temperate shorebirds. Oecologia 134, 332-342. https://doi.org/10.1007/s00442-002-1124-0.

Schmidt, N.M., Hardwick, B., Gilg, O., Høye, T.T., Krogh, P.H., Meltofte, H., Michelsen, A., Mosbacher, J.B., Raundrup, K., Reneerkens, J., Stewart, L., Wirta, H., Roslin, T., 2017. Interaction webs in arctic ecosystems: determinants of arctic change? Ambio 46, 12-25. https://doi.org/10.1007/s13280-016-0862-x.

Schmidt, N.M., Reneerkens, J., Christensen, J.H., Olesen, M., Roslin, T., 2019. An ecosystemwide reproductive failure with more snow in the Arctic. PLoS Biol. 17, e3000392. https://doi.org/10.1371/journal.pbio.3000392.

Skutch, A.F., 1949. Do tropical birds rear as many young as they can nourish? Ibis 91 , 430-455. https://doi.org/10.1111/j.1474-919X.1949.tb02293.x.

Smith, H.G., Källander, H., Hultman, J., Sanzén, B., 1989. Female nutritional state affects the rate of male incubation feeding in the pied flycatcher Ficedula hypoleuca. Behav. Ecol. Sociobiol. 24, 417-420. https://doi.org/10.1007/BF00293270.

Smith, P.A., Gilchrist, H.G., Smith, J.N.M., 2007. Effects of nest habitat, food, and parental behavior on shorebird nest success. Condor 109, 15-31. https://doi.org/10.1650/ 0010-5422(2007)109[15:EONHFA]2.0.CO;2.

Smith, P.A., Dauncey, S.A., Gilchrist, H.G., Forbes, M.R., 2012a. The influence of weather on shorebird Incubation. In: Ribic, C.A., Thompson III, F.R., Pietz, P.J. (Eds.), Video Surveillance of Nesting Birds, Studies in Avian Biology. Berkley, CA, pp. 89-104.

Smith, P.A., Tulp, I., Schekkerman, H., Gilchrist, H.G., Forbes, M.R., 2012b. Shorebird incubation behaviour and its influence on the risk of nest predation. Anim. Behav. 84, 835-842. https://doi.org/10.1016/j.anbehav.2012.07.004.

Soloviev, M.Y., Tomkovich, P.S., 1997. Body mass changes in waders (Charadrii) in a high arctic area at northern Taimyr, Siberia. J. Ornithol. 138, 271-281. https://doi.org/ 10.1007/BF01651552.

Steiger, S.S., Valcu, M., Spoelstra, K., Helm, B., Wikelski, M., Kempenaers, B., 2013. When the sun never sets: diverse activity rhythms under continuous daylight in freeliving arctic-breeding birds. Proc. R. Soc. B Biol. Sci. 280, 20131016. https://doi.org/ 10.1098/rspb.2013.1016.

Stow, D.A., Hope, A., McGuire, D., Verbyla, D., Gamon, J., Huemmrich, F., Houston, S., Racine, C., Sturm, M., Tape, K., Hinzman, L., Yoshikawa, K., Tweedie, C., Noyle, B., Silapaswan, C., Douglas, D., Griffith, B., Jia, G., Epstein, H., Walker, D., Daeschner, S., Petersen, A., Zhou, L., Myneni, R., 2004. Remote sensing of vegetation and landcover change in Arctic Tundra Ecosystems. Remote Sens. Environ. 89, 281-308. https://doi.org/10.1016/j.rse.2003.10.018.
Sweet, S.K, Asmus, A, Rich, M.E, Wingfield, J. Gough, L, Boelman, N.T, 2015. NDVI as a predictor of canopy arthropod biomass in the Alaskan arctic tundra. Ecol. Appl. 25, 779-790. https://doi.org/10.1890/14-0632.1.

Székely, T., Reynolds, J.D., 1995. Evolutionary transitions in parental care in shorebirds. Proc. R. Soc. Lond. B 262, 57-64. https://doi.org/10.1098/rspb.1995.0176.

Tape, K., Sturm, M., Racine, C., 2006. The evidence for shrub expansion in Northern Alaska and the Pan-Arctic. Glob. Chang. Biol. 12, 686-702. https://doi.org/10.1111/j.13652486.2006.01128.x

Tinbergen, J.M., Williams, J.B., 2002. Energetics of incubation. In: Incubation, Avian (Ed.), Behaviour, Environment and Evolution. D.C. Deeming, Oxford, pp. 299-313.

Tombre, I.M., Erikstad, K.E., 1996. An experimental study of Incubation effort in highArctic barnacle geese. J. Anim. Ecol. 65, 325-331. https://doi.org/10.2307/5878.

Tulp, I., Schekkerman, H., 2006. Time allocation between feeding and incubation in uniparental arctic-breeding shorebirds: energy reserves provide leeway in a tight schedule. J. Avian Biol. 37, 207-218. https://doi.org/10.1111/j.2006.0908-8857.03519.x.

Tulp, I., Schekkerman, H., 2008. Has prey availability for Arctic birds advanced with climate change? Hindcasting the abundance of tundra arthropods using weather and seasonal variation. Arctic 61, 48-60.

Tulp, I., Schekkerman, H., Chylarecki, P., Tomkovich, P., Soloviev, M.Y., Bruinzeel, L., Dijk K.V., Hildén, O., Hötker, H., Kania, W., Roomen, M.V., Sikora, A., Summers, R., 2002. Body mass patterns of little stints at different latitudes during incubation and chick-rearing. Ibis 144, 122-134. https://doi.org/10.1046/j.0019-1019.2001.00014.x.

Vleck, C.M., 1981. Energetic cost of Incubation in the Zebra finch. Condor 83, 229-237. https://doi.org/10.2307/1367313.

Weathers, W.W., Sullivan, K.A., 1989. Nest attentiveness and egg temperature in the yellow-eyed junco. Condor 91, 628-633. https://doi.org/10.2307/1368113.

Webb, D.R., 1987. Thermal tolerance of avian embryos: a review. Condor 89, 874-898. https://doi.org/10.2307/1368537.

Weidinger, K., 2002. Interactive effects of concealment, parental behaviour and predators on the survival of open passerine nests. J. Anim. Ecol. 71, 424-437. https://doi.org/ 10.1046/j.1365-2656.2002.00611.x.

White, F.N., Kinney, J.L., 1974. Avian Incubation. Science 186, 107-115.

Wiersma, P., Piersma, T., 1994. Effects of microhabitat, flocking, climate and migratory goal on energy expenditure in the annual cycle of red knots. Condor 96, 257-279. https://doi.org/10.2307/1369313.

Williams, G.C., 1966. Natural selection, the costs of reproduction, and a refinement of Lack's principle. Am. Nat. 100, 687-690. https://doi.org/10.1086/282461.

Yom-Tov, Y., Hilborn, R., 1981. Energetic constraints on clutch size and time of breeding in temperate zone birds. Oecologia 48, 234-243. https://doi.org/10.1007/BF00347969. 